Article

\title{
Comparative Study of Vortex-Induced Vibration of FRP Composite Risers with Large Length to Diameter Ratio Under Different Environmental Situations
}

\author{
Chunguang Wang ${ }^{1,2}$, Shiquan Ge ${ }^{1}$, Mingyu Sun ${ }^{3}$, Zhirong Jia ${ }^{1, * \mathbb{C}}$ and Baomin Han ${ }^{1, *}$ \\ 1 School of Civil and Architectural Engineering, Shandong University of Technology, Zibo 255000, China; \\ chw618@lehigh.edu (C.W.); sqge1991@gmail.com (S.G.) \\ 2 Department of Mechanical Engineering and Mechanics, Lehigh University, Bethlehem, PA 18015, USA \\ 3 School of Civil and Environmental Engineering, University of Illinois Urbana-Champaign, Champaign, \\ IL 61801-2352, USA; mingyus2@illinois.edu \\ * Correspondence: jiazhr@126.com (Z.J.); hanbm@sdut.edu.cn (B.H.); \\ Tel.: +86-533-278-1800 (Z.J.); +86-13561616178 (B.H.)
}

Received: 12 December 2018; Accepted: 30 January 2019; Published: 3 February 2019

\begin{abstract}
The increasing attraction of crude resources on the ocean floor leads to the development of risers, which are an indispensable component of an offshore oil and gas exploitation structure. High-grade steel is normally utilized for risers, however, fiber reinforced polymer (FRP) composite risers have become a feasible and economical alternative due to the desirable properties of the material. A comparative study of vortex-induced vibration (VIV) of FRP composite risers with two designed geometries were conducted and an X80 steel riser was used as the benchmark. The length to diameter ratios of all three risers were set to 100 and their VIV responses under different environmental situations, including the natural frequencies, global displacements, global stresses and the stress distributions in every composite layers, were obtained using computational fluid dynamics (CFD) simulation with coupled fluid-structure interaction. The VIV characteristics of both FRP composite risers and their distinction compared with that of steel risers were analyzed and discussed. From this paper, the dynamic characteristics in different environmental situations of VIV for FRP composite risers can be further understood.
\end{abstract}

Keywords: FRP composite riser with large length to diameter ratio; vortex-induced vibration; 3D finite element modelling; CFD simulation; fluid-structure interaction

\section{Introduction}

The consumption of oil and gas is exponentially increasing throughout the world. The limitation of crude resources of oil and gas on land makes the resources on the ocean floor more and more attractive. In order to achieve the offshore oil and natural gas extraction, many different types of production systems including conventional fixed platforms, tension-leg platforms, compliant towers, semi-submersibles and floating production facilities, have been employed. While these constructions vary mainly in the ways in which their platforms are positioned over sub-sea wells, the risers, both drilling risers which are used to guide a drilling stem and conduct the drilling fluid upwards, and production risers which raise the extracted oil or natural gas to a floating platform [1,2], are indispensable.

In offshore engineering, the material usually employed for structural components is high-grade steel. Nowadays, the utilization of fiber reinforced polymer (FRP) composites is gradually increasing due to their superior mechanical properties, low density and other desirable properties, such as better thermal insulation, and corrosion and fatigue resistance [3,4]. Therefore, it has been widely recognized 
that using FRP composites instead of steel for risers will lead to the significant reduction of operational costs and maintenance costs of the whole offshore production platform systems [5-7].

In order to apply FRP composites in offshore risers successfully, their durability in sea water is crucial. Venkatesan et al. [6] found that none of the long-term properties of carbon fiber reinforced polymer (CFRP) composites experienced any significant variations after exposure to pure water and seawater at different temperatures. On the other hand, many researchers $[3,4,8,9]$ found that the long-term tensile strength of a CFRP reduced to about $80-95 \%$ of its short-term values. For thermoplastic composite carbon/polyether ether ketone (PEEK), the transverse strength decreased obviously in boiling water [10] and therefore, the maximum service temperature of thermoplastic FRP composites has to be well below the glass transition temperatures of their polymer matrices. Moreover, in order to obtain reliable results using a numerical model, constitutive laws and damage models for FRP components have to be selected to optimize the accuracy of the numerical predictions [11].

Besides the research of mechanical properties of FRP composite materials in seawater, the responses and performances, including load distributions, fatigue, and vortex-induced vibrations (VIVs) of composite risers under environmental and functional loads have also been investigated [12-25]. The improvement of composite risers in performance over a pure metallic mandrel had been proved through a scaled-down test [23]. For the global response, the tension force decreases with an increasing water depth and the maximum bending moment occurs on the bottom, followed by the joints at the sea surface in general $[12-14,16,20,22]$. The axial tension and the bending moment throughout an entire composite riser are smaller due to its lower overall weight compared with steel risers [14,16]. The excellent fatigue resistance of FRP composites contributes to the better fatigue durability of composite risers, which was confirmed by previous studies $[13,14,16]$. More specifically, the structural composite body of the composite riser joint is likely to have an infinite fatigue life $[13,14,16]$, but still may vary depending on the choice of constituent materials and the manufacturing process. In terms of the VIV of composite risers, it is found that the fundamental frequency of a composite riser with the same boundary condition and geometry was higher than that of a steel riser [18] since the composite riser was much lighter and the value was relatively small [13,14]. The structural damping and tension variations were also significant to the VIV of composite risers [13], i.e., higher tension and damping could reduce VIV-induced fatigue [13,17]. A. F. Omar et al. [18] found that the maximum VIV stresses of a composite riser were much smaller than those of a steel riser, indicating the better fatigue lives of composite risers. Similarly, William Toh et al. [25] and L.B. Tan et al. [24] conducted comprehensive studies on both local and global scales on composite and steel risers using a finite element method and a larger safety margin for composite risers were observed. Although a composite riser without VIV suppression had a moderate VIV-induced fatigue damage, adding strakes and buoyancy modules to a composite riser could lead to even better VIV responses [13,24].

In addition, the design of a composite riser (thick composite tube) can be optimized to specific requirements by modifying some of its design variables, such as fiber and matrix combinations, fiber orientations, thicknesses of the liner and composite lamina, and stacking sequence, to enhance the benefits offered by FRP composites risers using different methods, e.g., finite element analysis [22,26-29], simple-input displacement-based method [30,31] and optimization algorithms [21,32-34].

Besides all these research studies, joint industry projects emerged several decades ago, and Table 1 summarizes some of them. 
Table 1. A summary of previous joint industry projects on composite risers.

\begin{tabular}{|c|c|c|c|}
\hline Year & Project/Funder & Riser Type * & Materials \\
\hline 1973 & Ahlstone [35] & $\mathrm{D}$ & glass fiber with epoxy \\
\hline $1980 \mathrm{~s}$ & $\begin{array}{c}\text { Institut Francais du Petrole and } \\
\text { Aerospatiale of France [36] }\end{array}$ & $\mathrm{P}$ & $\begin{array}{l}\text { glass and carbon fibers } \\
\text { with epoxy }\end{array}$ \\
\hline $1990 \mathrm{~s}$ & $\begin{array}{l}\text { National Institute of Standards and } \\
\text { Technology, Advanced Technology } \\
\text { Programs [37] }\end{array}$ & $P$ and $D$ & $\begin{array}{c}\text { carbon and E-glass fibers } \\
\text { with epoxy }\end{array}$ \\
\hline 1995-2001 & $\begin{array}{c}\text { Norske Conoco AS and Kvaerner Oilfield } \\
\text { Products [38] }\end{array}$ & $\mathrm{D}$ & $\begin{array}{l}\text { glass and carbon fiber } \\
\text { with epoxy }\end{array}$ \\
\hline 2003 & $\begin{array}{c}\text { ConocoPhillips, Kvaerner Oilfield Products } \\
\text { and ChevronTexaco }[39,40]\end{array}$ & $\mathrm{P}$ and $\mathrm{D}$ & carbon fiber with epoxy \\
\hline 2007 & $\begin{array}{c}\text { Doris Engineering, Freyssinet, Total and } \\
\text { Soficar [41] }\end{array}$ & $\mathrm{P}$ & $\begin{array}{l}\text { carbon fiber with } \\
\text { thermoplastic PA11 }\end{array}$ \\
\hline 2008-2011 & $\begin{array}{c}\text { Research Partnership to Secure Energy for } \\
\text { America [42] }\end{array}$ & $\mathrm{D}$ & carbon fiber with epoxy \\
\hline 2011 & Magma $[43,44]$ & $P$ and $\mathrm{D}$ & carbon fiber with PEEK \\
\hline
\end{tabular}

From all these research studies and joint industry projects, the feasibility, advantages and effectiveness of using FRP composites for risers have been proven, although no offshore riser currently being employed is made entirely of composites, except the demonstration composite drilling riser joint (a tube segment) installed in the field on the Heidrun TLP [38].

In this paper, three different risers with large length to diameter ratio, the X80 steel riser (riser 1), AS4-epoxy composites with titanium liner with geometries of (liner/90/(0/90) 10$)$ (riser 2) and (liner $\left./ 0_{3} /(+53,-53)_{5} / 90_{4}\right)$ (riser 3$)$ are selected to study their VIV characteristics. The CFD simulation with coupled fluid-structure interaction was achieved using ANSYS Workbench 17.1. Based on the combination of different risers, tension forces, buoyancies, gravities and current conditions, nine study cases were considered. The VIV responses under different situations of all these three risers were obtained, including the natural frequencies, global displacements, global stresses and the stress distributions in every layers of both FRP composite risers.

\section{Materials and Methods}

\subsection{Materials for the Risers}

In this study, X80 steel was utilized for steel riser and for composite risers, titanium alloy (Ti-6Al-4V) was used for the inner liner and AS4-epoxy was employed for the composite layers. The properties of these materials can be found in Tables 2 and 3 as well as in Figures 1 and 2. For the X80 steel (for riser 1) and titanium (for liner in risers 2 and 3), bilinear kinematic hardening model was selected to consider the elastic-plastic stage. For steel riser 1, 67\% of the yield stress of X80 was identified as the allowable stress according to American Bureau of Shipping (ABS) standard [45]. For the titanium liner in risers 2 and 3,59.5\% of the yield stress of titanium was regarded as the allowable stress [46]. In terms of the properties of unidirectional lamina of AS4-Epoxy FRP composites, an elastic model was considered, i.e., the plastic stage was disregarded. The maximum stress failure criterion [47] considered failures in the fiber direction, transverse direction and in-plane shear separately for all composite layers. In Table 3, subscripts 1, 2 and 3 represent the fiber direction, in-plane transverse direction and through-thickness direction of a composite lamina, respectively (Figure 2). 
Table 2. Properties of the materials for the steel riser and liner of composite riser.

\begin{tabular}{cccccccc}
\hline Material & $\begin{array}{c}\text { Density } \\
\left(\mathbf{k g} / \mathbf{m}^{\mathbf{3}}\right)\end{array}$ & $\begin{array}{c}\text { Modulus } \\
\mathbf{( G P a )}\end{array}$ & $\begin{array}{c}\text { Tangent } \\
\text { Modulus }(\mathrm{GPa})\end{array}$ & $\boldsymbol{v}$ & $\begin{array}{c}\text { Yield Stress } \\
\mathbf{( M P a})\end{array}$ & $\begin{array}{c}\text { Ultimate Stress } \\
\mathbf{( M P a})\end{array}$ & $\begin{array}{c}\text { Elongation at } \\
\text { Break (\%) }\end{array}$ \\
\hline X80 steel & 7850 & 207 & 1.25 & 0.3 & 555 & 625 & 5.868 \\
Titanium & 4430 & 113.8 & 0.53 & 0.342 & 880 & 950 & 14 \\
\hline
\end{tabular}

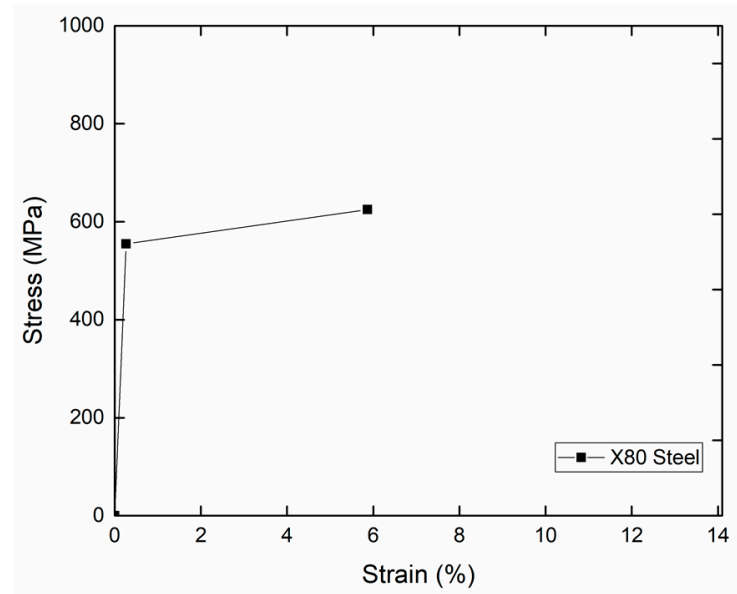

(a) X80 steel

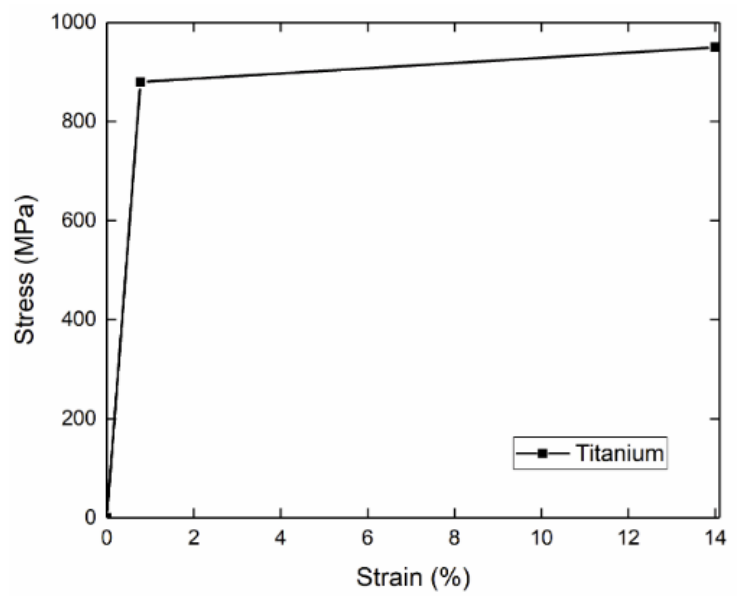

(b) titanium

Figure 1. Bilinear kinematic hardening model of (a) X80 steel and (b) titanium.

Table 3. Properties of unidirectional lamina of AS4-Epoxy for composite risers.

\begin{tabular}{|c|c|c|c|c|c|c|c|c|c|c|c|c|}
\hline Material & $\begin{array}{l}\text { Density } \\
\left(\mathrm{kg} / \mathrm{m}^{3}\right)\end{array}$ & $\begin{array}{c}\mathrm{E}_{1} \\
(\mathrm{GPa})\end{array}$ & $\begin{array}{c}\mathrm{E}_{2}=\mathrm{E}_{3} \\
(\mathrm{GPa})\end{array}$ & $\begin{array}{c}\mathrm{G}_{12}=\mathrm{G}_{13} \\
(\mathrm{GPa})\end{array}$ & $\begin{array}{c}v_{12}= \\
v_{13}\end{array}$ & $\begin{array}{c}\mathrm{G}_{23} \\
(\mathrm{GPa})\end{array}$ & $v_{23}$ & $\begin{array}{c}\sigma_{1}^{\mathbf{T}} \\
(\mathrm{MPa})\end{array}$ & $\begin{array}{c}\sigma_{1}^{\mathrm{C}} \\
(\mathrm{MPa})\end{array}$ & $\begin{array}{c}\sigma_{2}^{\mathrm{T}} \\
(\mathrm{MPa})\end{array}$ & $\begin{array}{c}\sigma_{2}^{\mathrm{C}} \\
(\mathrm{MPa})\end{array}$ & $\begin{array}{c}\tau_{12} \\
(\mathrm{MPa})\end{array}$ \\
\hline AS4-Epoxy & 1530 & 135.4 & 9.37 & 4.96 & 0.32 & 3.20 & 0.46 & 1732 & 1256 & 49.4 & 167.2 & 71.2 \\
\hline
\end{tabular}

Subscripts 1) fiber direction, 2) in-plane transverse and 3) through-thickness direction. Superscript $\mathrm{T}=$ Tension, $\mathrm{C}=$ Compression.

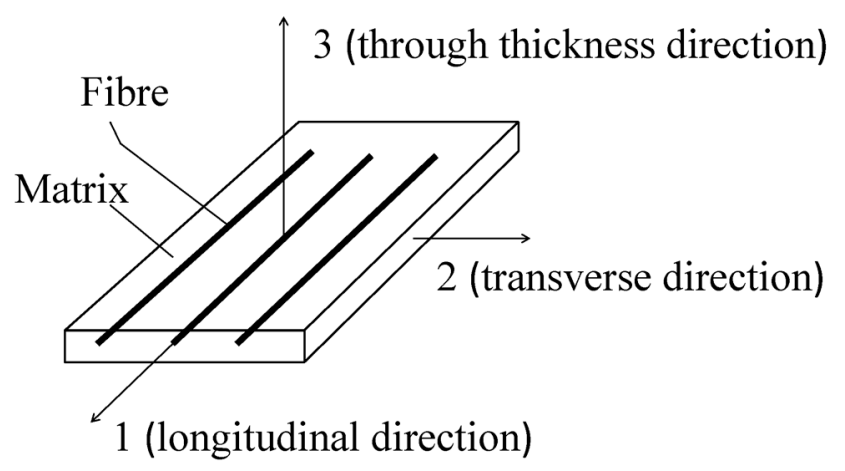

Figure 2. Lamina co-ordinate system.

\subsection{Riser Geometries}

Figure $3 \mathrm{a}, \mathrm{b}$ respectively show the cross-sections of the steel and composite riser joints in this study. The extracted fluids were transported by production tubings within the riser, which were protected by the riser joints and the riser joints carried all the structural loads. The internal diameters (IDs) of the steel and composite riser joints were fixed at $250 \mathrm{~mm}$ while, as the thickness of each joint was determined by the design to accommodate all the loads considered, their outer diameters (ODs) depended on the previous design results [20-22,27] (Table 4). From Table 4, the thicknesses for the steel riser (riser 1), AS4-epoxy composites and titanium liner with (liner/90/(0/90) 10$)$ (riser 2) and AS4-epoxy composites and titanium liner with (liner $\left./ 0_{3} /(+53,-53)_{5} / 90_{4}\right)($ riser 3$)$ were $25 \mathrm{~mm}$, 
$39.5 \mathrm{~mm}$ and $30.5 \mathrm{~mm}$, respectively. In other words, riser 2 was a conventional design of FRP composite riser while riser 3 was an optimized design of FRP composite riser. Both FRP composite risers $(59.6 \mathrm{~kg} / \mathrm{m}$ and $45.7 \mathrm{~kg} / \mathrm{m})$ achieved significant weight saving compared to the steel riser $(169 \mathrm{~kg} / \mathrm{m})$ and the optimized FRP composite riser 3 even led to a $23.3 \%$ weight reduction to the conventional FRP composite riser 2. For all the risers in this study the length to inner diameter ratios were 100 . The fiber angle of $0^{\circ}$ and $90^{\circ}$ were the axial and hoop directions of FRP composite risers, respectively (Figure 4).

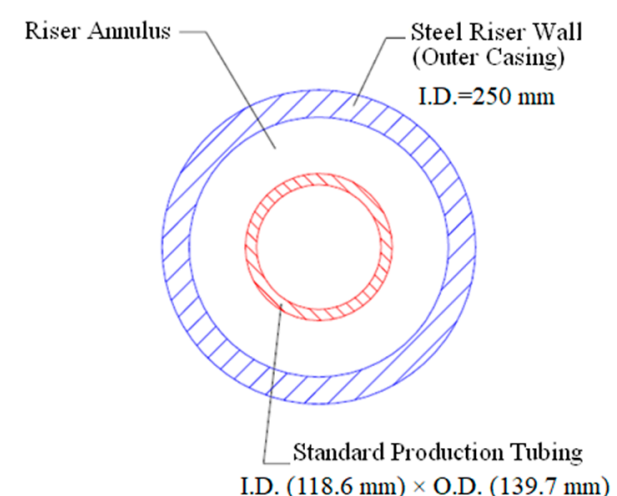

(a) steel riser joint

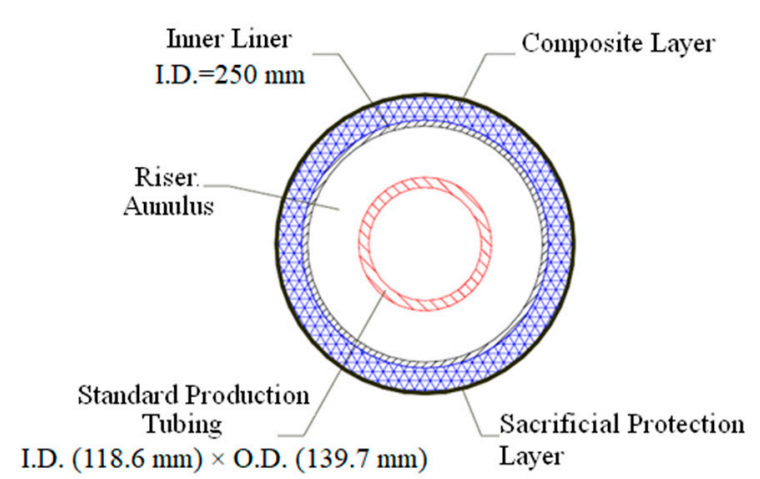

(b) composite riser joint

Figure 3. Cross-section for (a) steel riser joint and (b) composite riser joint.

Table 4. Geometries of risers.

\begin{tabular}{|c|c|c|c|c|c|c|c|c|c|}
\hline Riser & $\begin{array}{l}\text { I.D. } \\
\text { (m) }\end{array}$ & $\begin{array}{l}\text { O.D. } \\
\text { (m) }\end{array}$ & $\begin{array}{l}\text { Length } \\
\text { (m) }\end{array}$ & Lay-ups & $\begin{array}{l}\text { t_liner } \\
(\mathrm{mm})\end{array}$ & $\begin{array}{c}\mathrm{t} \_0 \\
(\mathrm{~mm})\end{array}$ & $\begin{array}{l}t_{-} \pm \theta \\
(\mathrm{mm})\end{array}$ & $\begin{array}{l}\mathbf{t} \_90 \\
(\mathbf{m m})\end{array}$ & $\begin{array}{l} \pm \theta \\
\left(^{\circ}\right)\end{array}$ \\
\hline 1 & 0.25 & 0.3 & 25 & X80 steel & & & & & \\
\hline 2 & 0.25 & 0.329 & 25 & {$\left[\right.$ liner $\left./ 90 /(0 / 90)_{10}\right]$} & 2 & 1.385 & & 2.15 & \\
\hline 3 & 0.25 & 0.311 & 25 & {$\left[\right.$ liner $\left./ 0_{3} /(+53,-53)_{5} / 90_{4}\right]$} & 2 & 1.70 & 1.64 & 1.75 & 53 \\
\hline
\end{tabular}

Subscript numbers in Lay-ups represent the numbers of lamina with different fiber reinforcement angle.

\subsection{FE Modelling and Study Cases}

ANSYS Workbench 17.1 was utilized for the comparative study of vortex-induced vibration (VIV) for the FRP composite risers and steel riser with length to diameter ratio of 100. Initially, the natural frequencies of all the risers were analyzed using pre-stress modal analysis. For FRP composite risers, ACP (Pre), Static Structural and Modal modules were involved while for steel risers, only Static Structural and Modal modules were required. In order to achieve the VIV simulation in ANSYS Workbench 17.1, the following modules were included: Geometry, ACP (Pre), Transient Structural, Fluid Flow, ACP (Post) and System Coupling [19]. Generally speaking, Geometry was utilized to create the geometries of risers and flow zones; ACP (Pre) and ACP (post) were employed to include the data of materials and lamination information for composite risers (risers 2 and 3 ) and to show the stress and deformation response of every composite laminae, respectively; Transient Structural was used to simulate the dynamic responses of risers; System Coupling was applied to achieve the data transfer between Transient Structural and Fluid Flow. As mentioned in Section 2.2, the geometries of composite risers 2 and 3 were obtained from the design results of Wang $[20,21,27]$ and the finite element modelling method had been verified by Kim [14] and Amaechi [26]. The difference here was the load conditions which was current flow with different velocities.

In this study, layered-structure method (LSM) [19] was employed for FRP composite riser simulation and their geometries are listed in Table 4. For the FRP composite risers, the data of material properties, the thicknesses of liner and composite laminate, reinforced fiber angles, the layer numbers of each lamina with different fiber orientations and the laminate stacking sequences were inputted in the module of ACP (Pre) and the stress and deformation response of every composite laminae 
were obtained in ACP (Post). The possible bond-slip effect is a significant phenomenon of FRP layers, and this can be checked indirectly in post-processing stage by comparing the maximum interface forces and stresses with the reference pull-out resistances [48]. However, in this paper, the numerical model of the composite riser using LSM assumed a rigid connection between the components, i.e., perfect bonding was assumed and no bond-slip effect was considered to simplify the modelling.

Then, the geometry and material data of FRP composite riser in ACP (Pre) were transferred to the Transient Structural module. Transient Structural was utilized to simulate the dynamic response of risers. In this module, the gravity, top-tension force, buoyancy, end support condition (simple support at the top end, fixed support at the bottom end) and the fluid solid interface were employed. After the whole simulation, the displacement history, global stress distribution etc., could be obtained.

Fluid Flow (Fluent) was used to simulate the flow conditions. 10D (Y-direction) $\times 20 \mathrm{D}$ (X-direction) $\times 25 \mathrm{~m}$ (Z-direction) was set as the flow dimension, where $\mathrm{D}$ was the outside diameter of the risers. Here $\mathrm{X}, \mathrm{Y}$ and $\mathrm{Z}$ directions were in-line flow direction, cross flow direction and depth direction, respectively. Large eddy simulation (LES) with bounded second order implicit transient formulation was selected as the mathematical model for turbulence in computational fluid dynamics (CFD), which reduced the computational cost with acceptable accuracy. The flow properties, such as flow density, kinematic viscosity coefficient and flow velocity listed in Table 5 were inputted in this module. The inlet, outlet, left, right, top and bottom sides were defined as the boundary conditions of velocity inlet, outflow, symmetry and wall, respectively.

To achieve the data transfer between Transient Structural and Fluid Flow, i.e., the two-way fluid structure interaction (FSI), module of System Coupling was utilized, and the simulation time (80 s) and step size $(0.2 \mathrm{~s})$ were set in this module.

The fluid grid of $5 \mathrm{D} \times 5 \mathrm{D}$ area around the riser was refined and set as the dynamic mesh zone with smoothing and re-meshing methods. Based on the results of convergence study, there were 1.15 million elements in the refined zone and 0.52 million elements for the other flow area, i.e., 1.67 million elements in total were employed in the flow zone. For the risers, 300 elements in axial direction and 20 elements in hoop direction were employed. In the though-thickness direction, one element, 22 elements and 18 elements for risers 1, 2 and 3, respectively. Note that, the laminate data were transferred from ACP (Pre) to Transient Structural and the number of elements in though-thickness direction was set as the number of layers of the structure automatically. In total, there were 6000 elements, 132,000 elements and 108,000 elements for risers 1, 2 and 3 respectively.

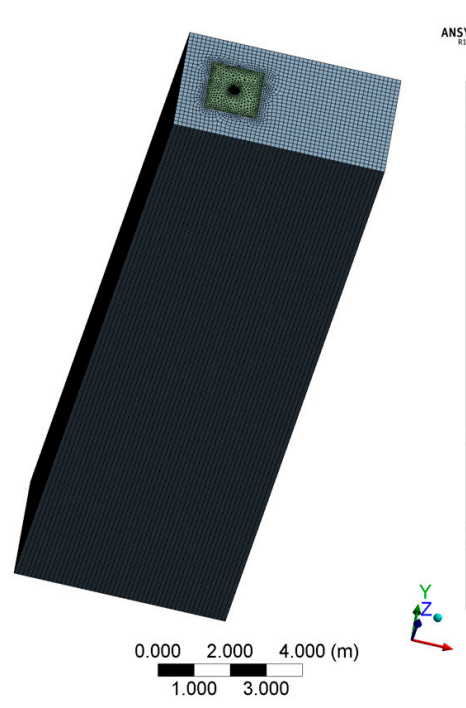

$\underset{\text { ANSYS }}{\text { HYI. }}$

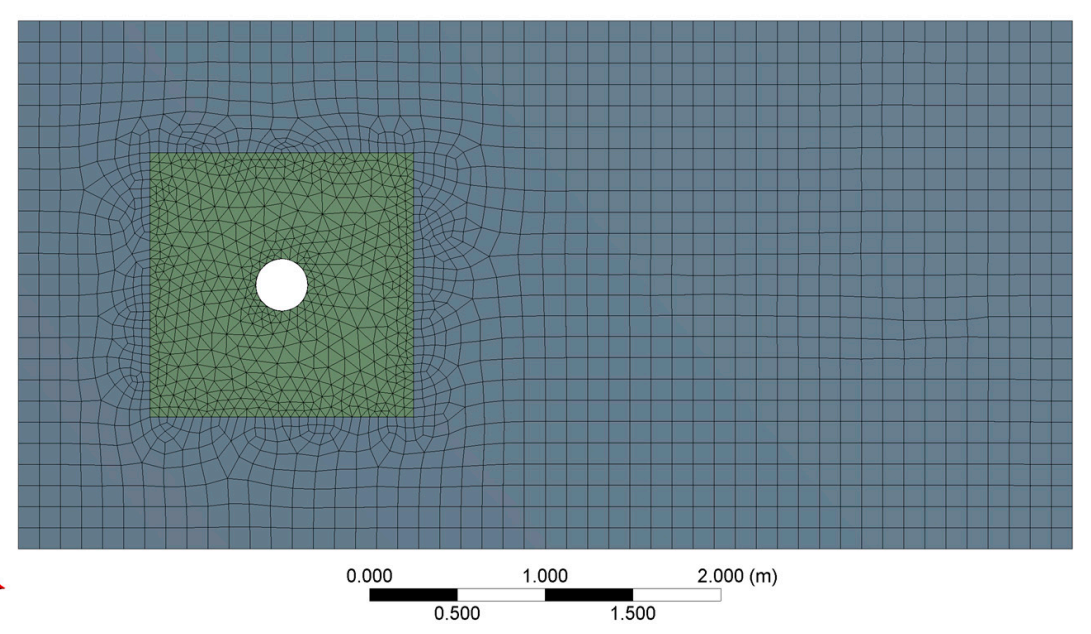

(a) flow mesh

Figure 4. Cont. 


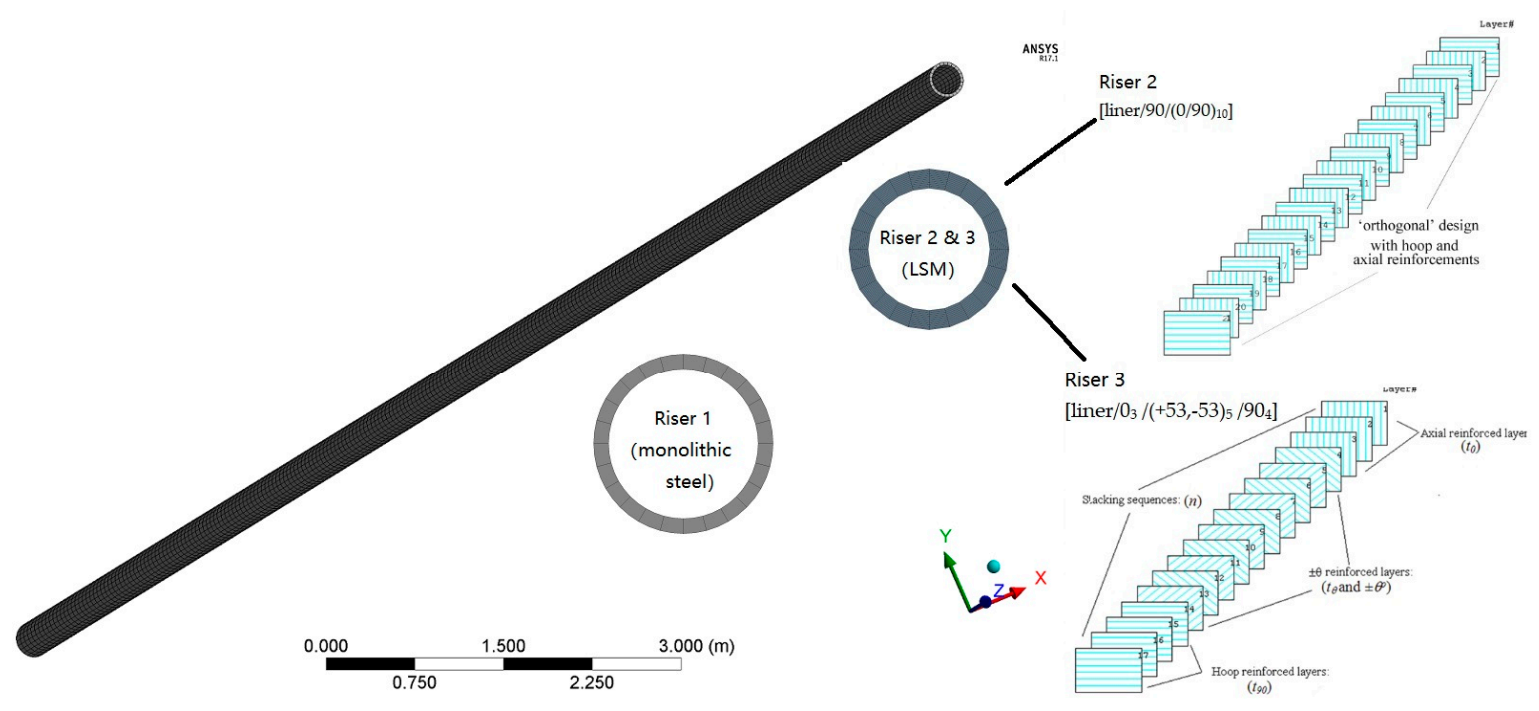

(b) riser mesh

Figure 4. FE models for (a) flow zone and (b) steel and FRP composite risers.

In this study, a tension was applied to the riser's top to keep its vertical position and the gravity, buoyancy and current load were also employed. The tension forces were set as 1.5 and 2 times the structural weight of steel and composite risers, respectively. The gravity and buoyancy loads were determined by the geometry of each riser. The current data of the Gulf of Mexico [2,14] was utilized according to the API Recommended Practice [49], which were $0.36 \mathrm{~m} / \mathrm{s}$ for a 1-year winter storm, $1.22 \mathrm{~m} / \mathrm{s}$ for a 100 -year hurricane and $2.13 \mathrm{~m} / \mathrm{s}$ for a 100-year loop current conditions. In the Gulf of Mexico, the sea water density is $1024 \mathrm{~kg} / \mathrm{m}^{3}$ and the kinematic viscosity coefficient $v$ is $1.06 \times$ $10^{-6}$. Table 5 shows the different cases in this study. Reynolds numbers for all the study cases were determined by Equation (1), where $\mathrm{U}$ is the flow velocity, $\mathrm{D}$ is the outside diameter of the riser, $v$ is kinematic viscosity coefficient. Turbulent intensity employed were calculated by Equation (2), where I is turbulent intensity and Re is Reynolds number.

$$
\begin{gathered}
\operatorname{Re}=\frac{\mathrm{UD}}{v} \\
\mathrm{I}=0.16 \operatorname{Re}^{(-1 / 8)}
\end{gathered}
$$

Table 5. Study cases.

\begin{tabular}{cccccccccc}
\hline $\begin{array}{c}\text { Case } \\
\text { No. }\end{array}$ & Riser & Re & $\begin{array}{c}\text { Flow } \\
\text { Density } \\
\mathbf{( k g / \mathbf { m } ^ { 3 } )}\end{array}$ & $\begin{array}{c}\text { Velocity } \\
\mathbf{( m / s )}\end{array}$ & $\begin{array}{c}\text { kinematic } \\
\text { Viscosity } \\
\text { Coefficient }\end{array}$ & $\begin{array}{c}\text { Turbulent } \\
\text { Intensity } \\
\mathbf{( \% )}\end{array}$ & $\begin{array}{c}\text { Gravity } \\
\mathbf{( N )}\end{array}$ & $\begin{array}{c}\text { Tension } \\
\text { Force (N) }\end{array}$ & $\begin{array}{c}\text { Buoyancy } \\
\mathbf{( N )}\end{array}$ \\
\hline 1 & 1 & 101,887 & 1024 & 0.36 & $1.06 \times 10^{-6}$ & 3.78 & 41,539 & 62,309 & 17,734 \\
2 & 2 & 111,736 & 1024 & 0.36 & $1.06 \times 10^{-6}$ & 3.74 & 14,592 & 29,183 & 21,328 \\
3 & 3 & 105,623 & 1024 & 0.36 & $1.06 \times 10^{-6}$ & 3.77 & 11,200 & 22,400 & 19,058 \\
4 & 1 & 345,283 & 1024 & 1.22 & $1.06 \times 10^{-6}$ & 3.25 & 41,539 & 62,309 & 17,734 \\
5 & 2 & 378,660 & 1024 & 1.22 & $1.06 \times 10^{-6}$ & 3.21 & 14,592 & 29,183 & 21,328 \\
6 & 3 & 357,943 & 1024 & 1.22 & $1.06 \times 10^{-6}$ & 3.23 & 11,200 & 22,400 & 19,058 \\
7 & 1 & 602,830 & 1024 & 2.13 & $1.06 \times 10^{-6}$ & 3.03 & 41,539 & 62,309 & 17,734 \\
8 & 2 & 661,104 & 1024 & 2.13 & $1.06 \times 10^{-6}$ & 3.00 & 14,592 & 29,183 & 21,328 \\
9 & 3 & 624,934 & 1024 & 2.13 & $1.06 \times 10^{-6}$ & 3.02 & 11,200 & 22,400 & 19,058 \\
\hline
\end{tabular}

From Table 5, it is clear that the top-tension forces required for composite risers were much smaller than that of the steel riser, although the tension force ratios of composite risers were larger (1.5 and 2 
respectively). This illustrates the benefit of composite risers in the weight reduction and the benefit would be more significant with the increasing length of risers.

\section{Results and Discussion}

In this section, the VIV responses under different situations of the three different risers were obtained and discussed. The large length to diameter ratio, fluid-structure interaction, different current velocities and different design geometries of FRP composite risers would affect each riser's VIV characteristics significantly.

\subsection{Natural Frequencies}

Natural frequency of the riser is a key characteristic in VIV analysis, because the "lock-in" would occur when the natural frequency of a riser is close to the vortex shedding frequency. The "lock-in" phenomenon would lead to fatigue failure of the riser because of the large and damaging vibration. The vortex shedding frequency can be calculated by Equation (3) which includes the Strouhal number $S_{t}$, the outside diameter of the riser $\mathrm{D}$ and the flow velocity $\mathrm{U}$. According to the relationship between Re and $S_{t}$, the Strouhal number $S_{t}$ is 0.2 for Re between 300 and 300,000 and is $0.2-0.3$ for Re between 300,000 and 3,500,000 [50]. More specifically, the $S_{t}$ are 0.2 for cases 1-3, 0.21 for cases $4-6$ and 0.22 for cases 7-9.

$$
\mathrm{f}_{\mathrm{s}}=\frac{\mathrm{S}_{\mathrm{t}} \mathrm{U}}{\mathrm{D}}
$$

In addition, the possibility of a riser's "lock-in" using reduced velocity $U_{\mathrm{r}}$ was estimated using Equation (4). When $U_{r}$ ranges 4-8 [50], "lock-in" may occur. The $U_{r}$ of all the risers are listed in Table 6.

$$
\mathrm{U}_{\mathrm{r}}=\frac{\mathrm{U}}{\mathrm{f}_{\mathrm{n}} \mathrm{D}}
$$

The natural frequencies and first three modal shapes for all the risers are presented in Figure 5 and Table 6 . Note that all the risers have similar modal shapes and therefore only the first three modal shapes of FRP composite riser 3 are showed as an example.
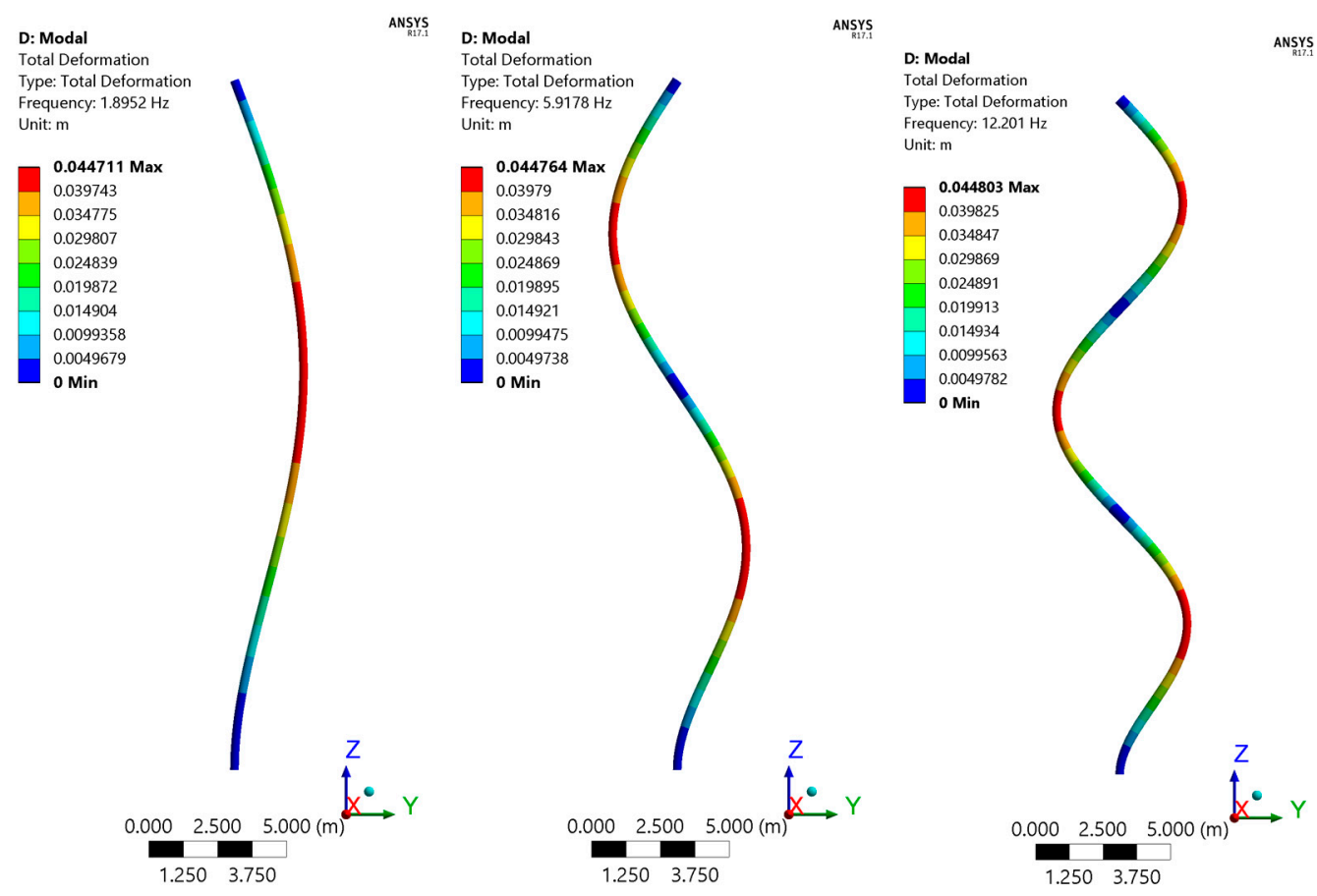

Figure 5. First three mode shapes of fiber reinforced polymer (FRP) composite riser 3. 
Table 6. Natural frequencies, vortex shedding frequencies and reduced velocities of the risers.

\begin{tabular}{cccccccccc}
\hline \multirow{2}{*}{ Property } & \multicolumn{3}{c}{ Riser 1 } & \multicolumn{3}{c}{ Riser 2 } & & Riser 3 \\
\cline { 2 - 10 } & Case 1 & Case 4 & Case 7 & Case 2 & Case 5 & Case 8 & Case 3 & Case 6 & Case 9 \\
\hline natural frequency $\mathrm{f}_{\mathrm{n}} /(\mathrm{Hz})$ & & 2.01 & & & 2.45 & & & 1.89 & \\
vortex shedding frequency & 0.24 & 0.85 & 1.56 & 0.22 & 0.78 & 1.42 & 0.23 & 0.82 & 1.51 \\
$\begin{array}{c}\mathrm{f}_{\mathrm{s}} /(\mathrm{Hz}) \\
\text { reduced velocity } \mathrm{U}_{\mathrm{r}}\end{array}$ & 0.60 & 2.02 & 3.53 & 0.45 & 1.51 & 2.64 & 0.61 & 2.06 & 3.61 \\
\hline
\end{tabular}

From the results listed in Table 6, it can be seen the natural frequencies of cases 7 (riser 1) and case 9 (riser 3 ) are close to their vortex shedding frequencies, and similarly the reduced velocity $U_{r}$ of these two cases are close to the range of 4-8. Hence, for these two cases, "lock-in" might occur. We have to notice that Equation (3) of vortex shedding frequency and Equation (4) of reduced velocity are calculated based on the rigid cylinder without deformation and fluid structure interaction.

\subsection{Time History of Displacements for All Three Risers}

The time history of displacements in in-line flow direction $(\mathrm{X})$ and cross flow direction $(\mathrm{Y})$ for all risers in different cases are plotted in Figures 6 and 7, respectively. In order to show the comparison more clearly, the displacements in both directions were normalized by the O.D. of the risers. For all the risers, three typical locations, i.e., $-6 \mathrm{~m},-12.5 \mathrm{~m}$ and $-19 \mathrm{~m}$, were selected.

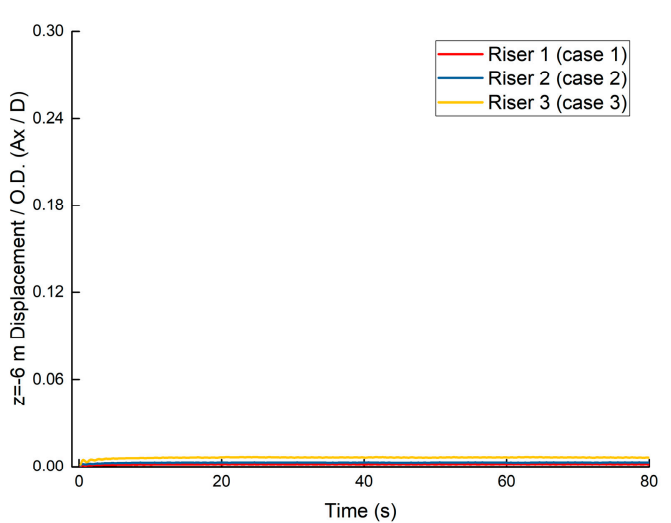

(a) $\mathrm{v}=0.36 \mathrm{~m} / \mathrm{s}(-6 \mathrm{~m})$

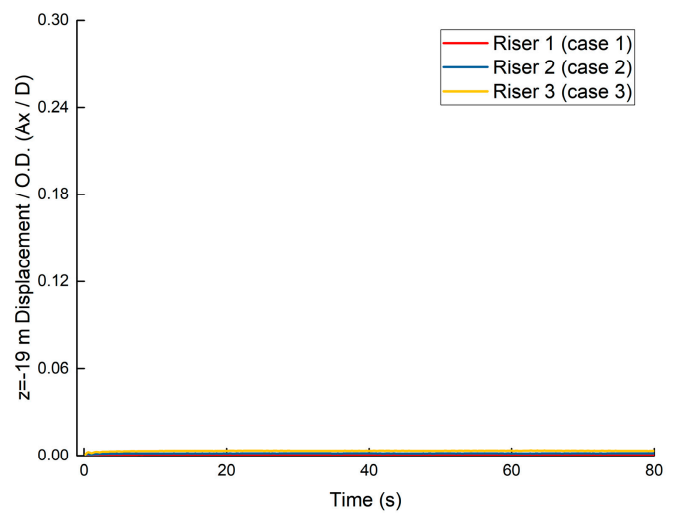

(c) $\mathrm{v}=0.36 \mathrm{~m} / \mathrm{s}(-19 \mathrm{~m})$

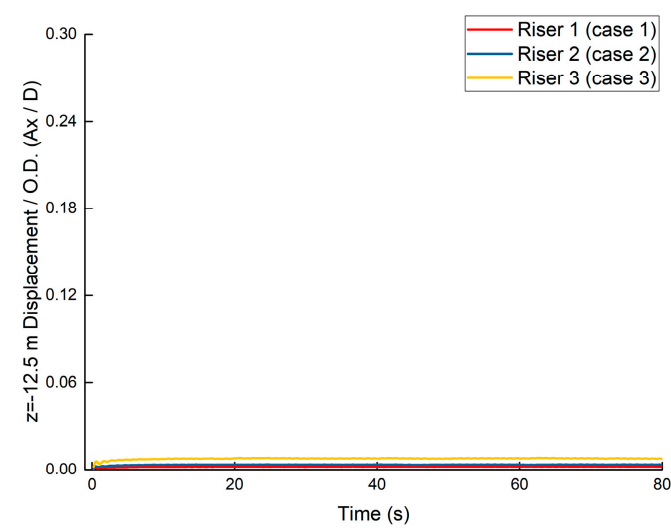

(b) $\mathrm{v}=0.36 \mathrm{~m} / \mathrm{s}(-12.5 \mathrm{~m})$

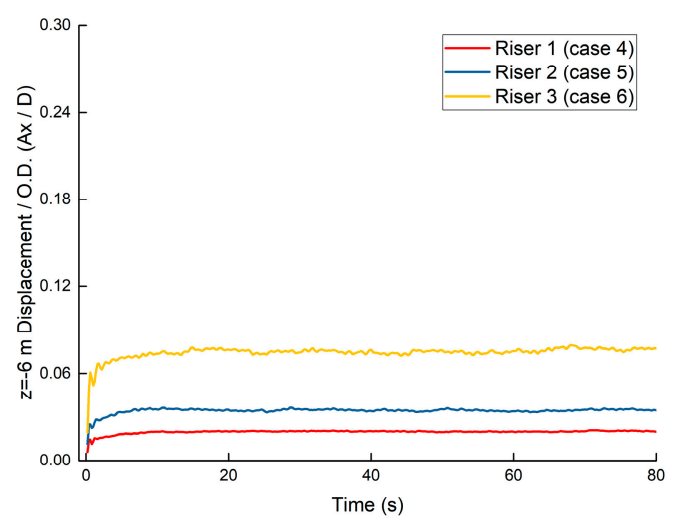

(d) $\mathrm{v}=1.22 \mathrm{~m} / \mathrm{s}(-6 \mathrm{~m})$

Figure 6. Cont. 


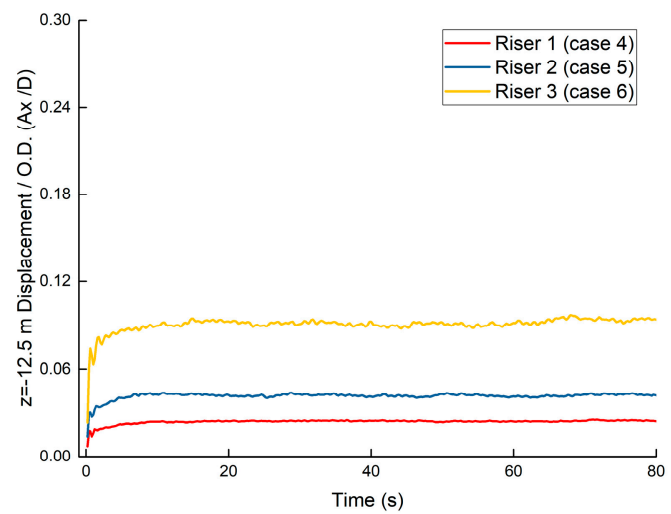

(e) $\mathrm{v}=1.22 \mathrm{~m} / \mathrm{s}(-12.5 \mathrm{~m})$

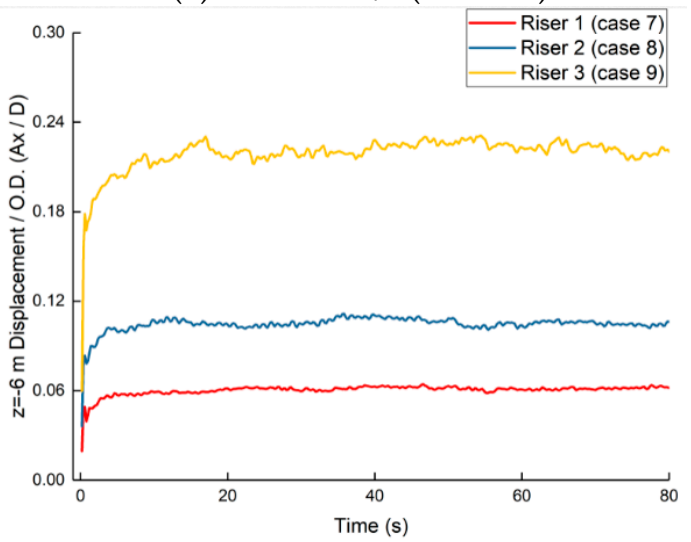

$(\mathrm{g}) \mathrm{v}=2.13 \mathrm{~m} / \mathrm{s}(-6 \mathrm{~m})$

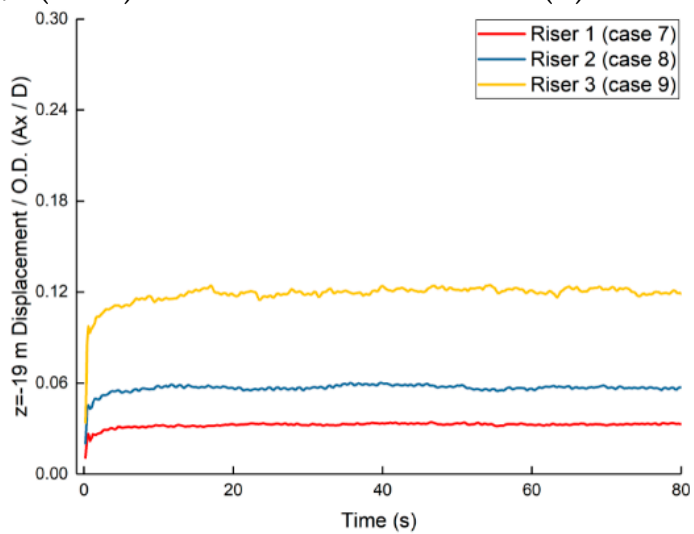

(i) $\mathrm{v}=2.13 \mathrm{~m} / \mathrm{s}(-19 \mathrm{~m})$

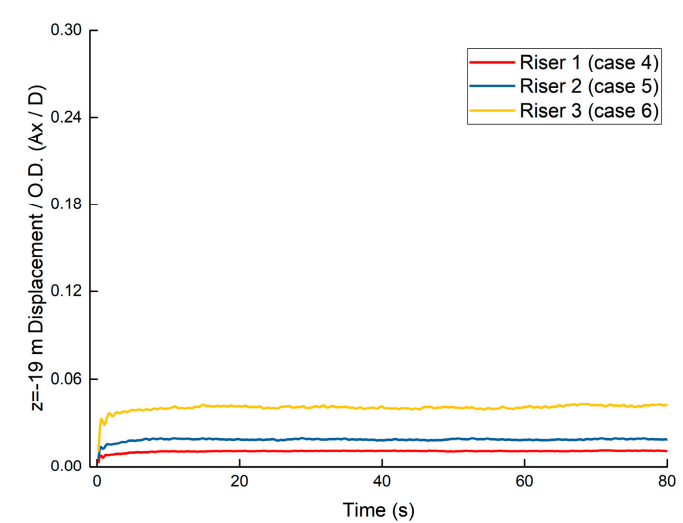

(f) $\mathrm{v}=1.22 \mathrm{~m} / \mathrm{s}(-19 \mathrm{~m})$

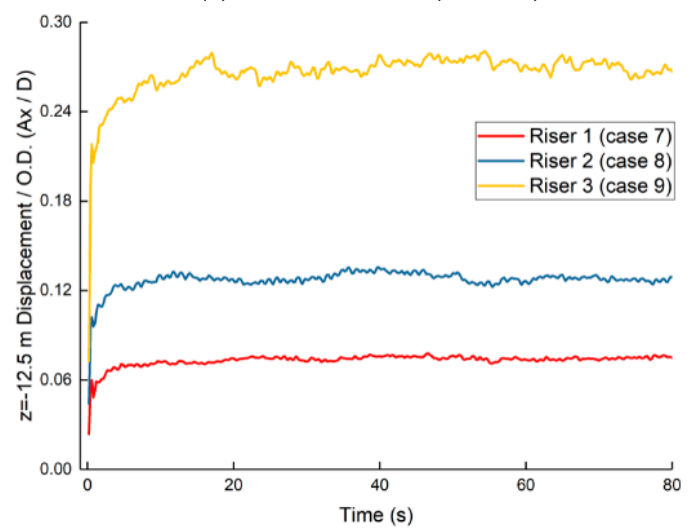

(h) $\mathrm{v}=2.13 \mathrm{~m} / \mathrm{s}(-12.5 \mathrm{~m})$

Figure 6. Time history of displacements in in-line flow direction $(X)$ at three typical locations.

From Figure 6, it is clear that the in-line flow direction $(X)$ displacements maintained at a relatively stable value and vibrate slightly after the initial growth for all three risers and at all locations. More specifically, for velocities equal to $0.36 \mathrm{~m} / \mathrm{s}$, the maximum displacements in flow direction/outside diameter (Ax/D) of risers 1,2 and 3 were around $0.0017,0.003$ and 0.0065 at $-6 \mathrm{~m}$, $0.002,0.0036$ and 0.008 at $-12.5 \mathrm{~m}$ and $0.0009,0.0016$ and 0.0035 at $-19 \mathrm{~m}$, respectively. For velocities equal to $1.22 \mathrm{~m} / \mathrm{s}$, the maximum displacements in flow direction/outside diameter (Ax/D) of risers 1,2 and 3 were $0.02,0.035$ and 0.075 at $-6 \mathrm{~m}, 0.024,0.042$ and 0.095 at $-12.5 \mathrm{~m}$ and $0.011,0.019$ and 0.042 at $-19 \mathrm{~m}$, respectively. For velocities equal to $2.13 \mathrm{~m} / \mathrm{s}$, the maximum displacements in flow direction/outside diameter (Ax/D) of risers 1,2 and 3 were $0.06,0.10$ and 0.23 at $-6 \mathrm{~m}, 0.075,0.128$ and 0.274 at $-12.5 \mathrm{~m}$ and $0.033,0.057$ and 0.12 at $-19 \mathrm{~m}$, respectively. To summarize: (1) In the cases with the same current velocity, the displacement of riser 3 was the largest, followed by riser 2, and riser 1 
was the smallest for all locations of the three risers. (2) With the increase of current velocity, the Ax/D rose for all three risers. Take riser 3 at $12.5 \mathrm{~m}$ for example, the $\mathrm{Ax} / \mathrm{D}(\mathrm{s})$ was about 11 times $(1.22 \mathrm{~m} / \mathrm{s})$ and 32 times $(2.13 \mathrm{~m} / \mathrm{s})$ of that at $0.36 \mathrm{~m} / \mathrm{s}$. (3) The end support conditions affected the displacement significantly, i.e., simple support lead to larger displacement. Using riser 3 at $2.13 \mathrm{~m} / \mathrm{s}$ as an example, the $\mathrm{Ax} / \mathrm{D}(\mathrm{s})$ was about 0.23 at $-6 \mathrm{~m}(6 \mathrm{~m}$ to the simple support end) and 0.12 at $-19 \mathrm{~m}(6 \mathrm{~m}$ to the fixed support end).

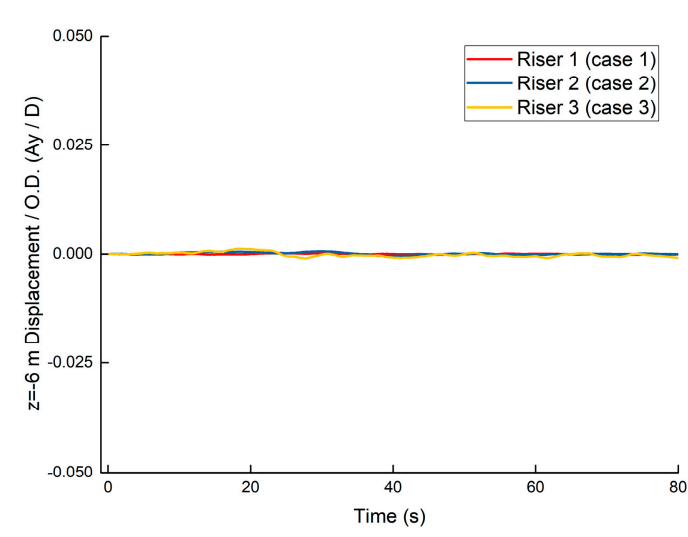

(a) $\mathrm{v}=0.36 \mathrm{~m} / \mathrm{s}(-6 \mathrm{~m})$

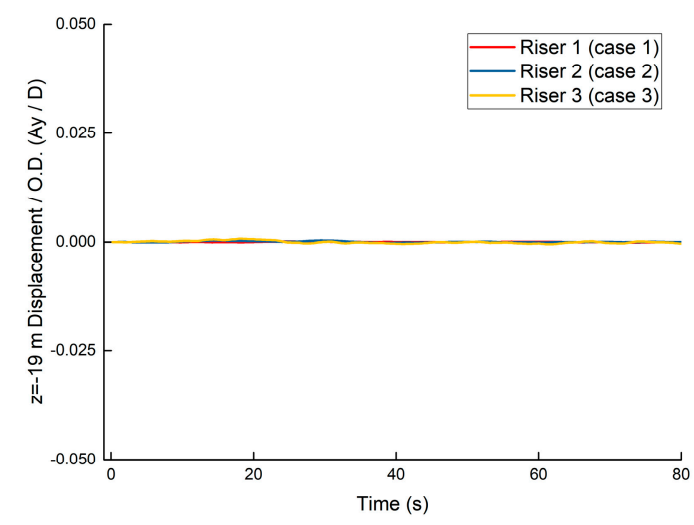

(c) $\mathrm{v}=0.36 \mathrm{~m} / \mathrm{s}(-19 \mathrm{~m})$

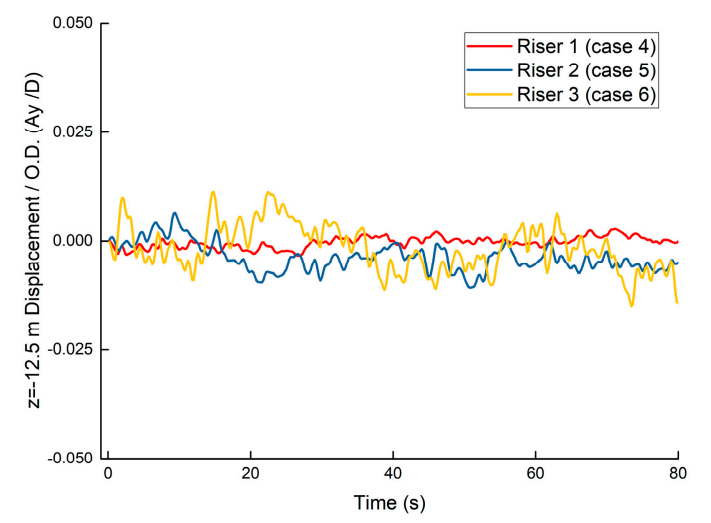

(e) $\mathrm{v}=1.22 \mathrm{~m} / \mathrm{s}(-12.5 \mathrm{~m})$

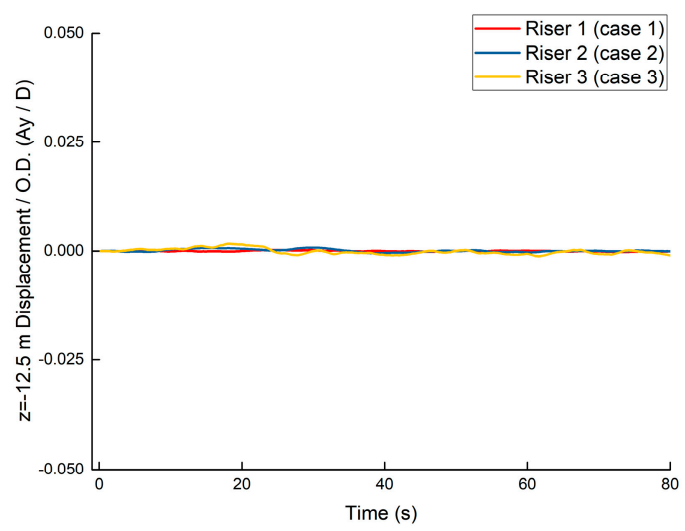

(b) $\mathrm{v}=0.36 \mathrm{~m} / \mathrm{s}(-12.5 \mathrm{~m})$

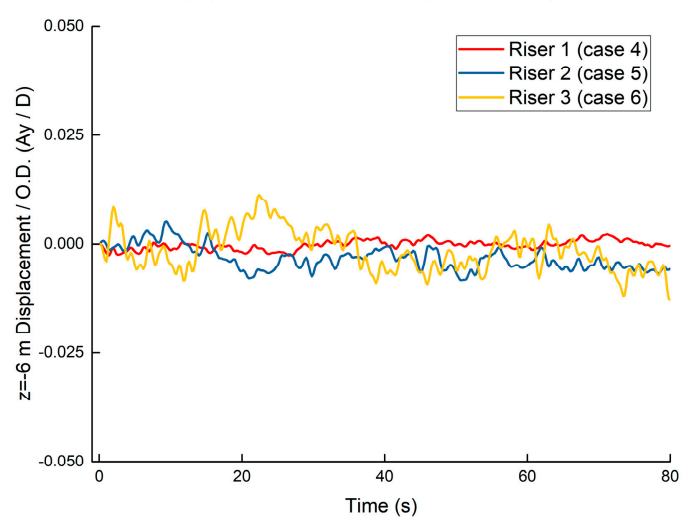

(d) $\mathrm{v}=1.22 \mathrm{~m} / \mathrm{s}(-6 \mathrm{~m})$

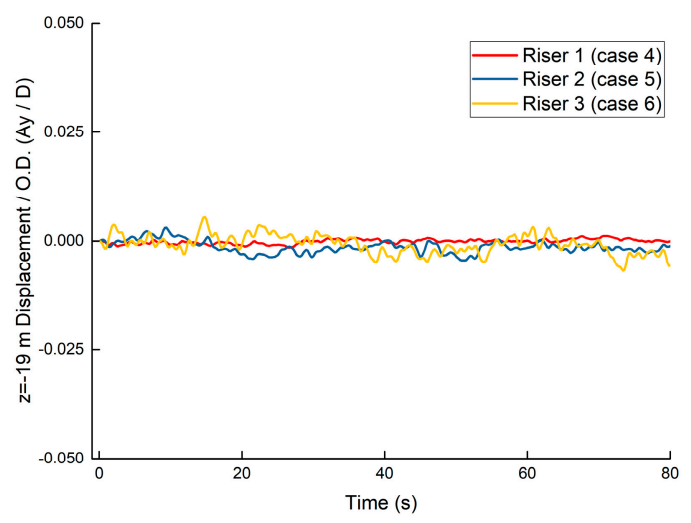

(f) $\mathrm{v}=1.22 \mathrm{~m} / \mathrm{s}(-19 \mathrm{~m})$

Figure 7. Cont. 


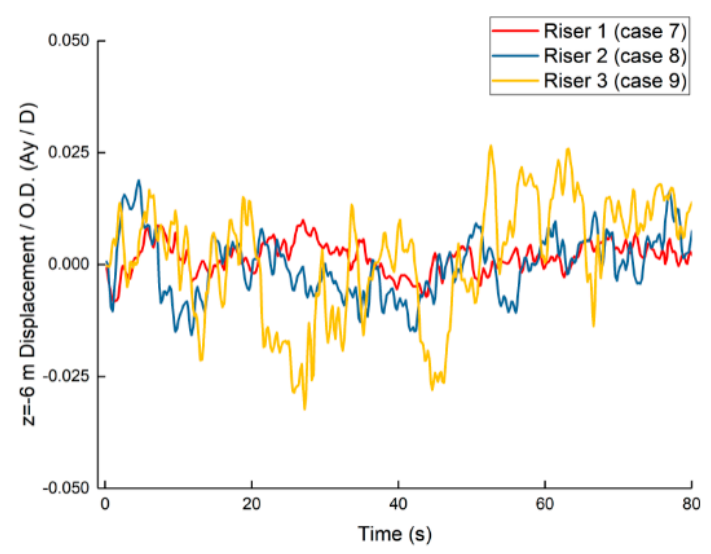

$(\mathrm{g}) \mathrm{v}=2.13 \mathrm{~m} / \mathrm{s}(-6 \mathrm{~m})$

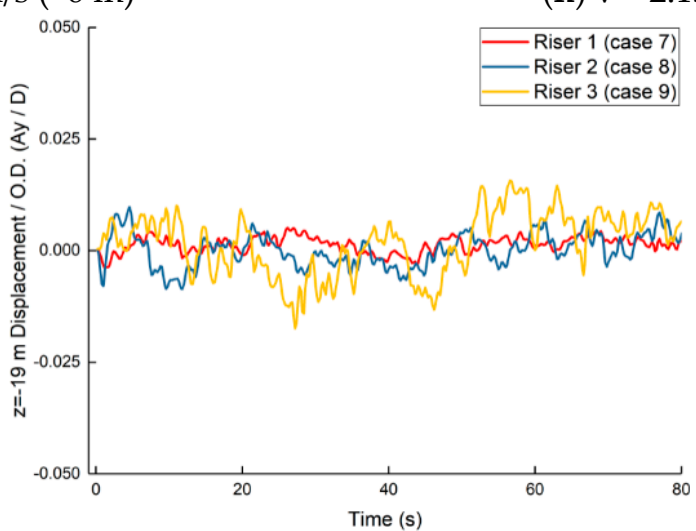

(i) $\mathrm{v}=2.13 \mathrm{~m} / \mathrm{s}(-19 \mathrm{~m})$

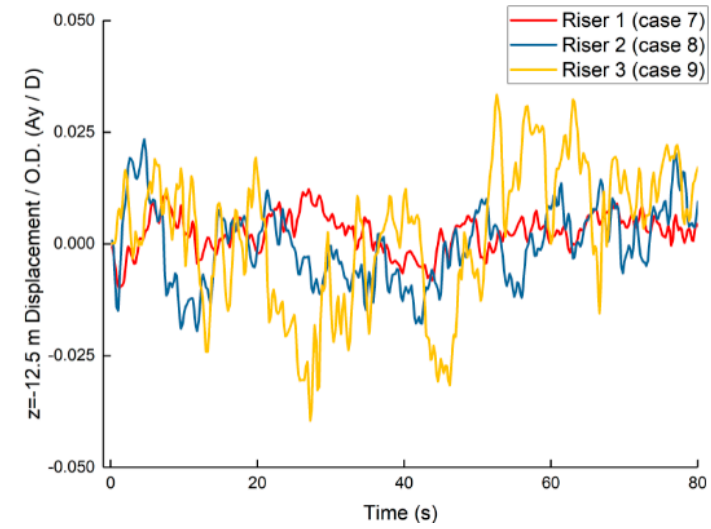

(h) $\mathrm{v}=2.13 \mathrm{~m} / \mathrm{s}(-12.5 \mathrm{~m})$

Figure 7. Time history of displacements in cross flow direction (Y) at three typical locations.

From Figure 7, it is clear that the cross-flow direction $(\mathrm{Y})$ displacements of all risers vibrated obviously. The vibrations for the cases with $0.36 \mathrm{~m} / \mathrm{s}$ were comparatively more stable than those for the cases with $1.22 \mathrm{~m} / \mathrm{s}$ and $2.13 \mathrm{~m} / \mathrm{s}$. This was because for cases 1-3 $(0.36 \mathrm{~m} / \mathrm{s})$, the Re (s) was $101,887,111,736$ and 105,623 and therefore the vortex streets for these cases were fully turbulent [50]. For cases 4-9, the Re (s) was between 300,000 and 3,500,000 and therefore the laminar boundary layer underwent turbulent transition and the wake was narrower and disorganized [50]. More specifically, for velocities equal to $0.36 \mathrm{~m} / \mathrm{s}$, the maximum range of displacements in cross-flow direction/outside diameter (Ay/D) of riser 1, 2 and 3 were around $0.0004,0.001$ and 0.002 at $-6 \mathrm{~m}, 0.0005,0.0018$ and 0.003 at $-12.5 \mathrm{~m}$ and $0.0002,0.0006$ and 0.0013 at $-19 \mathrm{~m}$, respectively. For velocities equal to $1.22 \mathrm{~m} / \mathrm{s}$, the maximum ranges of displacements in cross-flow direction/outside diameter (Ay/D) of risers 1 , 2 and 3 were $0.005,0.014$ and 0.024 at $-6 \mathrm{~m}, 0.006,0.017$ and 0.026 at $-12.5 \mathrm{~m}$ and $0.003,0.0075$ and 0.012 at $-19 \mathrm{~m}$, respectively. For velocities equal to $2.13 \mathrm{~m} / \mathrm{s}$, maximum ranges of displacements in cross-flow direction/outside diameter (Ay/D) of risers 1, 2 and 3 were $0.018,0.035$ and 0.059 at $-6 \mathrm{~m}$, $0.022,0.043$ and 0.073 at $-12.5 \mathrm{~m}$ and $0.009,0.018$ and 0.033 at $-19 \mathrm{~m}$, respectively. To summarize: (1) In the cases with the same current velocity, the vibration range of riser 3 was the largest, followed by riser 2, and riser 1 was the smallest for all locations of the three risers. (2) With the increase of current velocity, the Ay/D rose for all three risers. Take riser 3 at $12.5 \mathrm{~m}$ for an example, the Ay/D(s) was about 9 times $(1.22 \mathrm{~m} / \mathrm{s})$ and 24 times $(2.13 \mathrm{~m} / \mathrm{s})$ of that at $0.36 \mathrm{~m} / \mathrm{s}$. (3) the end support conditions affected the displacement significantly, i.e., the simple support lead to larger vibration. Using riser 3 at $2.13 \mathrm{~m} / \mathrm{s}$ as an example, the Ay/D(s) were about 0.059 at $-6 \mathrm{~m}(6 \mathrm{~m}$ to the simple support $\mathrm{end})$ and 0.033 at $-19 \mathrm{~m}$ ( $6 \mathrm{~m}$ to the fixed support end). 


\subsection{Maximum Displacements and Von Mises Stresses of All Three Risers}

Similarly, the time history of displacements in in-line flow direction $(\mathrm{X})$, cross flow direction (Y) and von Mises stresses for all locations of risers can be acquired. According to these data, the maximum displacements and stresses at different locations of risers are obtained and presented in Figures 8-12.

Figure 8 a shows the maximum Ax/D for a velocity of $0.36 \mathrm{~m} / \mathrm{s}$, Figure $8 \mathrm{~b}$ presents the maximum Ax/D for velocity of a $1.22 \mathrm{~m} / \mathrm{s}$, and Figure 8c illustrates the maximum Ax/D for a velocity of $2.13 \mathrm{~m} / \mathrm{s}$.

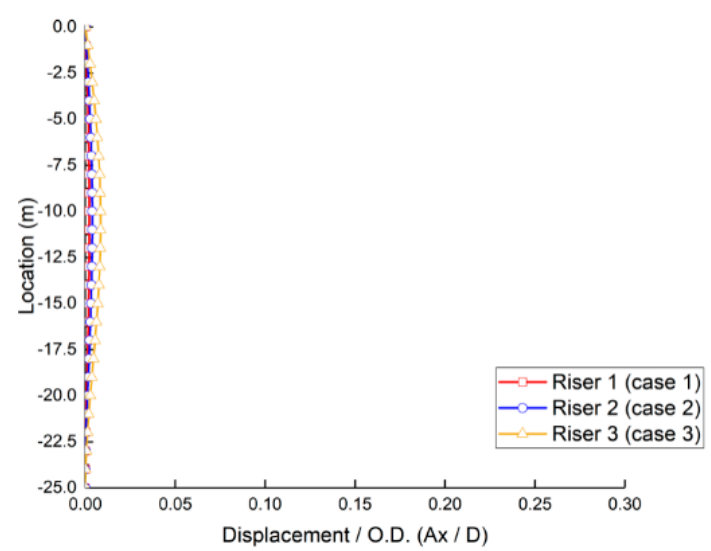

(a) $\mathrm{v}=0.36 \mathrm{~m} / \mathrm{s}$

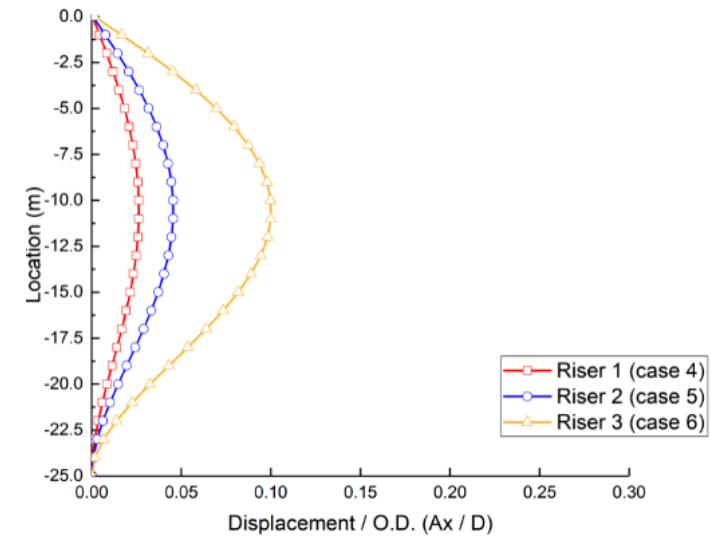

(b) $\mathrm{v}=1.22 \mathrm{~m} / \mathrm{s}$

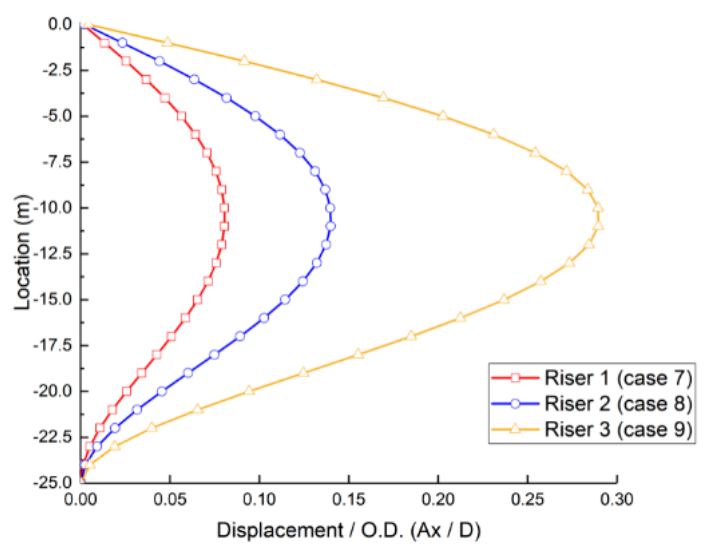

(c) $\mathrm{v}=2.13 \mathrm{~m} / \mathrm{s}$

Figure 8. Maximum displacements/outside diameter $(\mathrm{Ax} / \mathrm{D})$ in in-line flow direction $(\mathrm{X})$ of all three risers.

From Figure 8, for all cases riser 3 had the maximum Ax/D and riser 1 had the minimum Ax/D. Also it could be found that the maximum Ax/D occurred above the middle point of each riser, which indicated the simple support lead to larger displacement compared with the fixed support. Based on Figure 8 and the procedure of creating it, the maximum Ax/D for risers 1, 2 and 3 for $0.36 \mathrm{~m} / \mathrm{s}$ were 0.0023 at $-11 \mathrm{~m}(60.6 \mathrm{~s}), 0.0039$ at $-11 \mathrm{~m}(74.6 \mathrm{~s})$ and 0.0085 at $-11 \mathrm{~m}$ (62.6 s), respectively. The maximum Ax/D for risers 1, 2 and 3 for $1.22 \mathrm{~m} / \mathrm{s}$ were 0.0263 at $-11 \mathrm{~m}(71.0 \mathrm{~s}), 0.0455$ at $-11 \mathrm{~m}$ (28.8 s) and 0.100 at $-11 \mathrm{~m}(68.0 \mathrm{~s})$, respectively. The maximum Ax/D for risers 1, 2 and 3 for $2.13 \mathrm{~m} / \mathrm{s}$ were 0.0805 at $-11 \mathrm{~m}(46.6 \mathrm{~s}), 0.140$ at $-11 \mathrm{~m}(39.8 \mathrm{~s})$ and 0.290 at $-11 \mathrm{~m}$ (54.4 s), respectively.

Figure 9 a shows the maximum Ay/D for velocity of $0.36 \mathrm{~m} / \mathrm{s}$, Figure $9 \mathrm{~b}$ presents the maximum Ay/D for velocity of $1.22 \mathrm{~m} / \mathrm{s}$, and Figure 9c illustrates the maximum Ay/D for velocity of $2.13 \mathrm{~m} / \mathrm{s}$. 


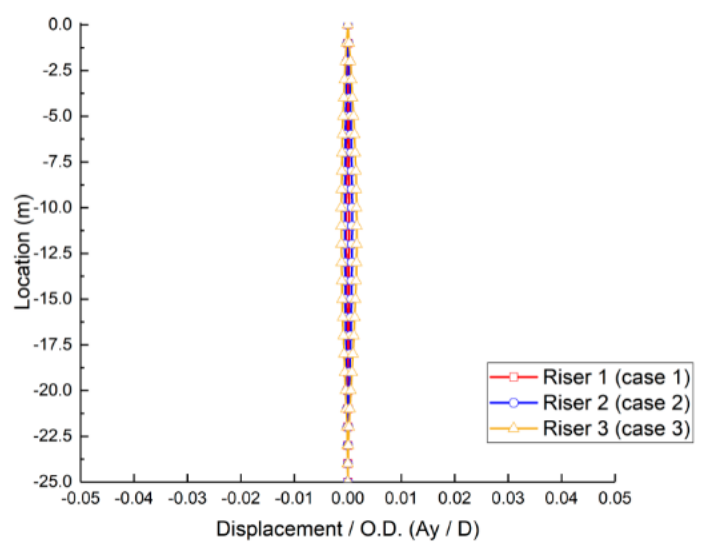

(a) $\mathrm{v}=0.36 \mathrm{~m} / \mathrm{s}$

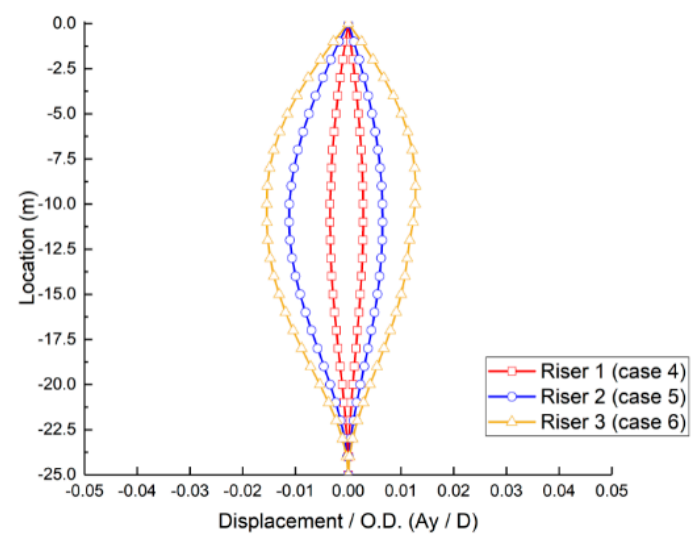

(b) $\mathrm{v}=1.22 \mathrm{~m} / \mathrm{s}$

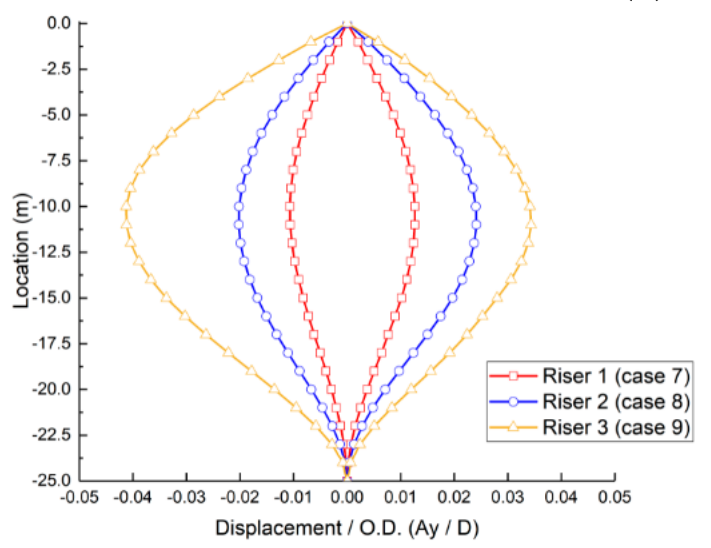

(c) $\mathrm{v}=2.13 \mathrm{~m} / \mathrm{s}$

Figure 9. Maximum displacements cross flow direction $(\mathrm{Y})$ of all three risers.

From Figure 9, for all cases riser 3 had the maximum ranges of Ay/D and riser 1 had the minimum ranges of Ay/D. Also it could be found that the maximum ranges of Ay/D occurred above the middle point of each riser, which indicated the simple support lead to larger vibrations compared with the fixed support. Based on Figure 9 and the procedure of creating it, the maximum ranges of Ay/D for risers 1,2 and 3 for $0.36 \mathrm{~m} / \mathrm{s}$ were 0.00048 at $-11 \mathrm{~m}, 0.0019$ at $-11 \mathrm{~m}$ and 0.003 at $-11 \mathrm{~m}$, respectively. The maximum ranges of Ay/D for risers 1, 2 and 3 for $1.22 \mathrm{~m} / \mathrm{s}$ were 0.0063 at $-11 \mathrm{~m}, 0.018$ at $-11 \mathrm{~m}$ and 0.0282 at $-9 \mathrm{~m}$, respectively. The maximum ranges of Ay/D for risers 1, 2 and 3 for $2.13 \mathrm{~m} / \mathrm{s}$ were 0.0233 at $-10 \mathrm{~m}, 0.044$ at $-11 \mathrm{~m}$ and 0.076 at $-11 \mathrm{~m}$, respectively. Here it is noted that the maximum Ay/D and the minimum Ay/D occurred at different times, and therefore no time was measured for the maximum range of Ay/D.

From Figures 8 and 9, the in-line displacement was much larger than the cross flow displacement. Based on the time when the maximum Ax/D occur for all cases, Figure 10 presents the total displacement distributions of riser 3 at those specified times. Here we have to note, the displacement distributions of risers 1 and 2 were similar to those of riser 3, and the only difference was the specific maximum displacement value for each riser. More specifically, the maximum displacements for riser 1 were $0.00071 \mathrm{~m}$ at $60.6 \mathrm{~s}, 0.0079 \mathrm{~m}$ at $71 \mathrm{~s}$ and $0.024 \mathrm{~m}$ at $46.6 \mathrm{~s}$ for flow velocities of $0.36 \mathrm{~m} / \mathrm{s}, 1.22 \mathrm{~m} / \mathrm{s}$ and $2.13 \mathrm{~m} / \mathrm{s}$ respectively, the maximum displacements for riser 2 were $0.0013 \mathrm{~m}$ at $74.6 \mathrm{~s}, 0.015 \mathrm{~m}$ at $28.8 \mathrm{~s}$ and $0.046 \mathrm{~m}$ at $39.8 \mathrm{~s}$ for flow velocities of $0.36 \mathrm{~m} / \mathrm{s}, 1.22 \mathrm{~m} / \mathrm{s}$ and $2.13 \mathrm{~m} / \mathrm{s}$ respectively, and the maximum displacements for riser 3 were $0.0027 \mathrm{~m}$ at $62.6 \mathrm{~s}, 0.031 \mathrm{~m}$ at $68 \mathrm{~s}$ and $0.090 \mathrm{~m}$ at $54.4 \mathrm{~s}$ for flow velocities of $0.36 \mathrm{~m} / \mathrm{s}, 1.22 \mathrm{~m} / \mathrm{s}$ and $2.13 \mathrm{~m} / \mathrm{s}$ respectively. 


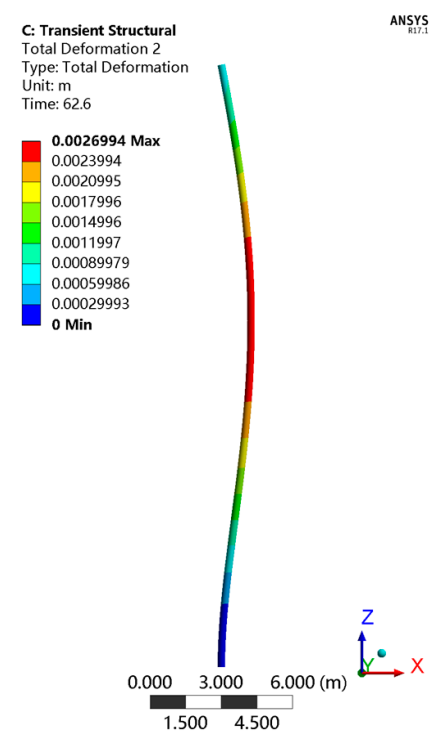

(a) riser 3 at $62.6 \mathrm{~s}$ with $0.36 \mathrm{~m} / \mathrm{s}$

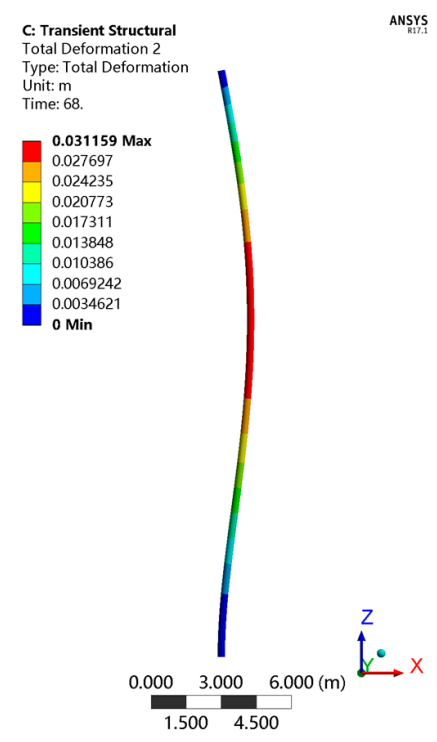

(b) riser 3 at $68.0 \mathrm{~s}$ with 1.22 $\mathrm{m} / \mathrm{s}$

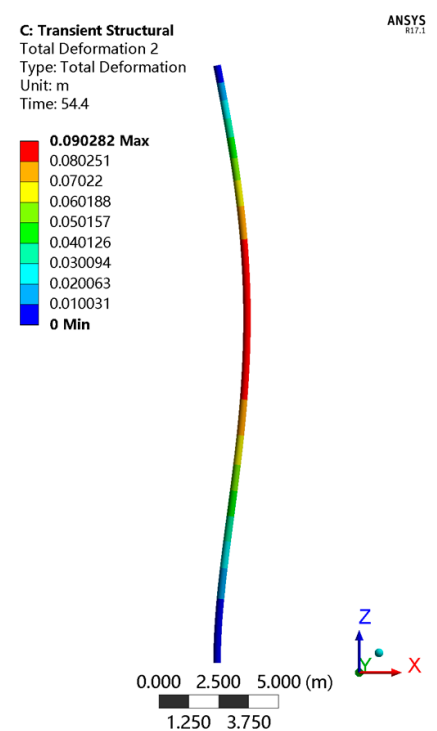

(c) riser 3 at $54.4 \mathrm{~s}$ with $2.13 \mathrm{~m} / \mathrm{s}$

Figure 10. Maximum displacement of the riser 3: (a) at $62.6 \mathrm{~s}$ with $0.36 \mathrm{~m} / \mathrm{s},(\mathbf{b})$ at $68.0 \mathrm{~s}$ with $1.22 \mathrm{~m} / \mathrm{s}$ and (c) at $54.4 \mathrm{~s}$ with $2.13 \mathrm{~m} / \mathrm{s}$.

Figure 11 shows the maximum von Mises stresses of all three risers for the velocity of $0.36 \mathrm{~m} / \mathrm{s}$, $1.22 \mathrm{~m} / \mathrm{s}$, and $2.13 \mathrm{~m} / \mathrm{s}$, respectively.

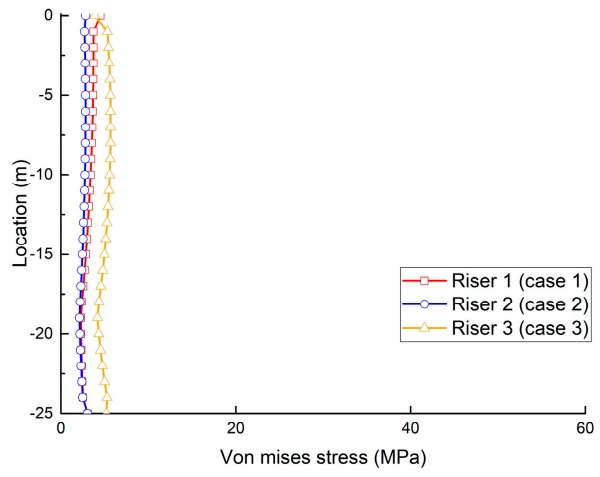

(a) $\mathrm{v}=0.36 \mathrm{~m} / \mathrm{s}$

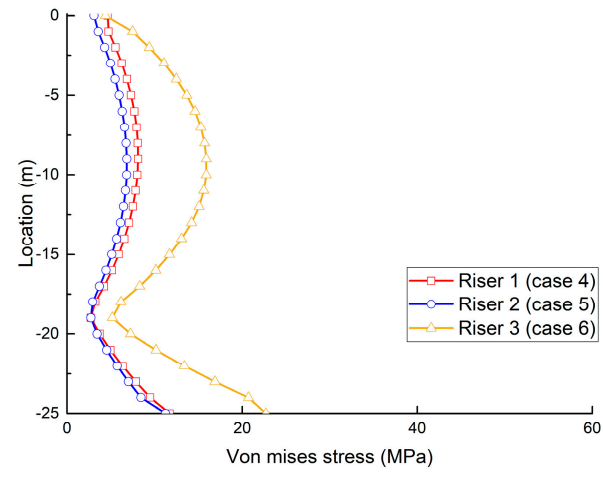

(b) $\mathrm{v}=1.22 \mathrm{~m} / \mathrm{s}$

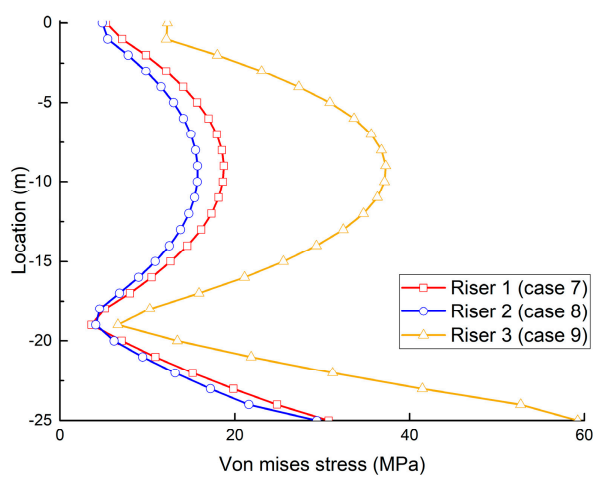

(c) $\mathrm{v}=2.13 \mathrm{~m} / \mathrm{s}$

Figure 11. Maximum von Mises stresses of all three risers. 
From Figure 11, for all cases riser 3 had the maximum von Mises stresses and riser 2 had the minimum von Mises stresses. Here we have to note that, only the von Mises stresses for steel riser (riser 1) could be utilized to verify the failure, more specifically, the $67 \%$ of the yield stress of X80 steel (371 MPa) was identified as the allowable stress according to American Bureau of Shipping (ABS) standard [45]. Therefore, for all cases, steel risers would not incur stress failure. The minimum factors of safety, which are defined as allowable strength/stress, were 82.4, 31.6 and 12.1 for steel riser 1 with current velocities of $0.36 \mathrm{~m} / \mathrm{s}, 1.22 \mathrm{~m} / \mathrm{s}$ and $2.13 \mathrm{~m} / \mathrm{s}$, respectively. However, the von Mises stresses for FRP composite risers (risers 2 and 3) could not be utilized to verify the failure because the global stresses could not represent the stress distributions in each composite laminae. If the equivalent stresses of a composite riser is required, the effective modulus method (EMM) rather than the layered-structure method (LSM) should be utilized [19]. In this paper, the global stress distributions for FRP composite risers here were only used to find the locations and time of the maximum stresses occurred, and this information was used for failure verification of FRP composite risers in the next section.

For all cases, the maximum von Mises stresses occurred at the top/bottom end of all risers, followed by the middle parts (above the middle point) of the risers, while at about $-19 \mathrm{~m}$, the minimum von Mises stresses happened. The reasons for this trend were that the fixed support at the bottom lead to the maximum stresses and the middle parts had the largest deformation attributed to large stresses as well. For the small velocity situation, top-tension force lead to the maximum von Mises stress at the top end, especially for the steel riser whose tension force was the largest. For the location around $-19 \mathrm{~m}$, all risers had comparatively small deformation and it was relatively far from the fixed support, therefore, minimum von Mises stresses occurred.

Based on Figure 11 and the procedure of creating it, the maximum von Mises stresses for risers 1, 2 and 3 for $0.36 \mathrm{~m} / \mathrm{s}$ were $4.5 \mathrm{MPa}$ at $0 \mathrm{~m}(72.6 \mathrm{~s}), 3.0 \mathrm{MPa}$ at $-25 \mathrm{~m}(30.6 \mathrm{~s})$ and $5.7 \mathrm{MPa}$ at $-7 \mathrm{~m}(24.6 \mathrm{~s})$, respectively. The maximum von Mises stresses for risers 1,2 and 3 for $1.22 \mathrm{~m} / \mathrm{s}$ were $11.7 \mathrm{MPa}$ at $-25 \mathrm{~m}(71.0 \mathrm{~s}), 11.3 \mathrm{MPa}$ at $-25 \mathrm{~m}(52.6 \mathrm{~s})$ and $22.7 \mathrm{MPa}$ at $-25 \mathrm{~m}(68.0 \mathrm{~s})$, respectively. The maximum von Mises stresses for risers 1, 2 and 3 for $2.13 \mathrm{~m} / \mathrm{s}$ were $30.7 \mathrm{MPa}$ at $-25 \mathrm{~m}(46.6 \mathrm{~s}), 29.4 \mathrm{MPa}$ at $-25 \mathrm{~m}$ (39.8 s) and $59.2 \mathrm{MPa}$ at $-25 \mathrm{~m}(54.4 \mathrm{~s})$, respectively.

According to the time when the maximum von Mises stresses occurred for all cases, Figure 12 presents the stress distributions of all risers at those specified time.

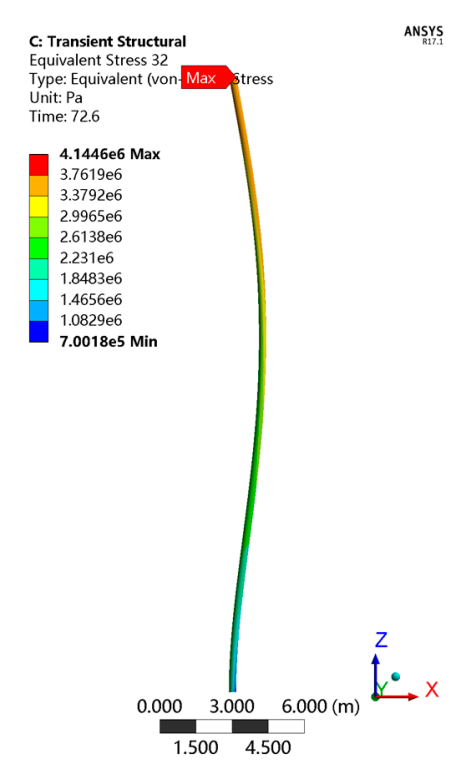

(a) riser 1 at $72.6 \mathrm{~s}$ with $0.36 \mathrm{~m} / \mathrm{s}$

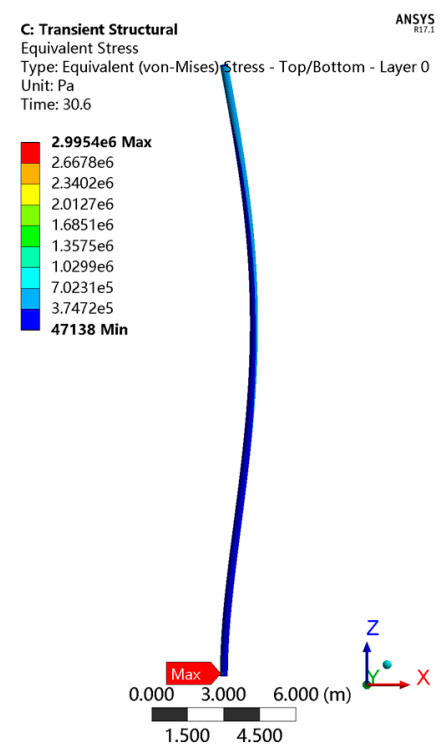

(b) riser 2 at $30.6 \mathrm{~s}$ with $0.36 \mathrm{~m} / \mathrm{s}$

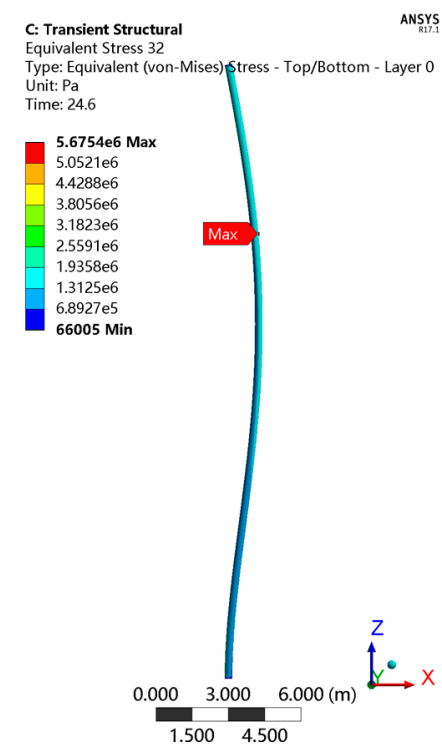

(c) riser 3 at $24.6 \mathrm{~s}$ with $0.36 \mathrm{~m} / \mathrm{s}$

Figure 12. Cont. 


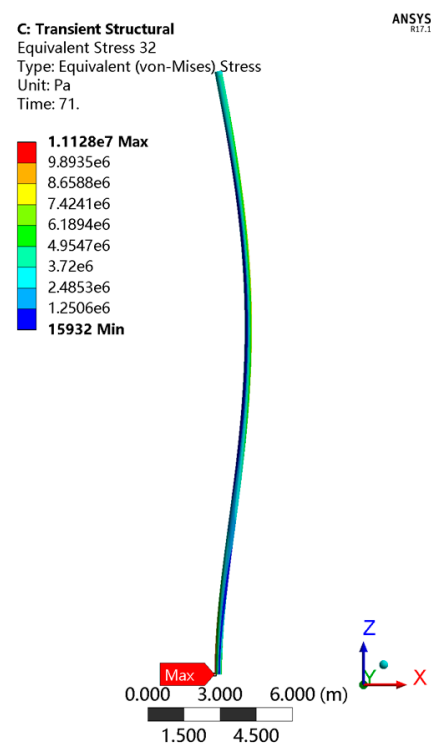

(d) riser 1 at $71.0 \mathrm{~s}$ with $1.22 \mathrm{~m} / \mathrm{s}$

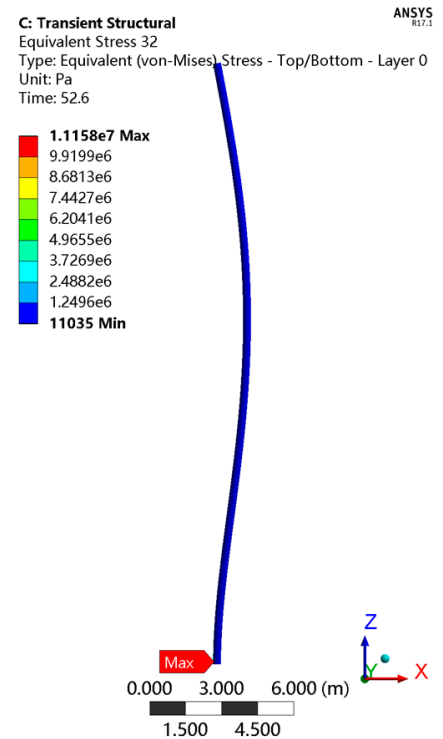

(e) riser 2 at $52.6 \mathrm{~s}$ with $1.22 \mathrm{~m} / \mathrm{s}$

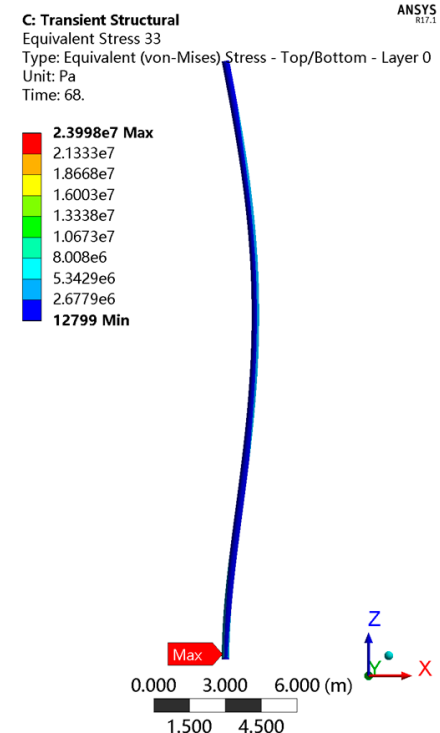

(f) riser 3 at $68.0 \mathrm{~s}$ with $1.22 \mathrm{~m} / \mathrm{s}$

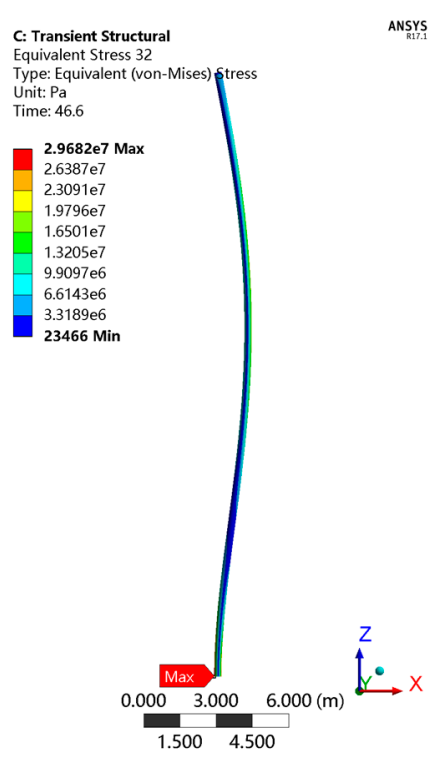

(g) riser 1 at $46.6 \mathrm{~s}$ with $2.13 \mathrm{~m} / \mathrm{s}$

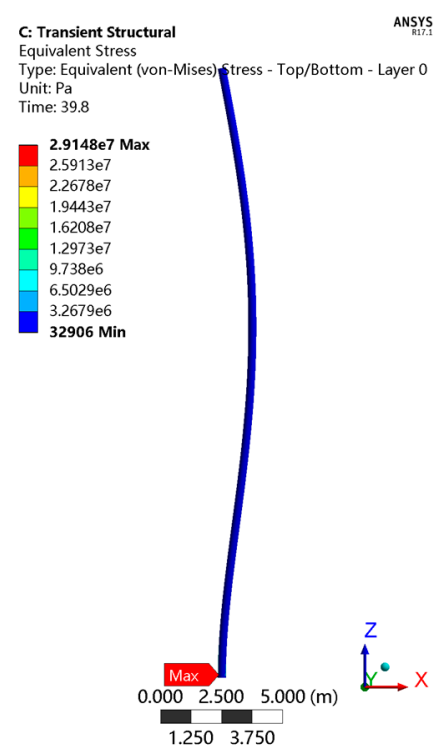

(h) riser 2 at $39.8 \mathrm{~s}$ with $2.13 \mathrm{~m} / \mathrm{s}$

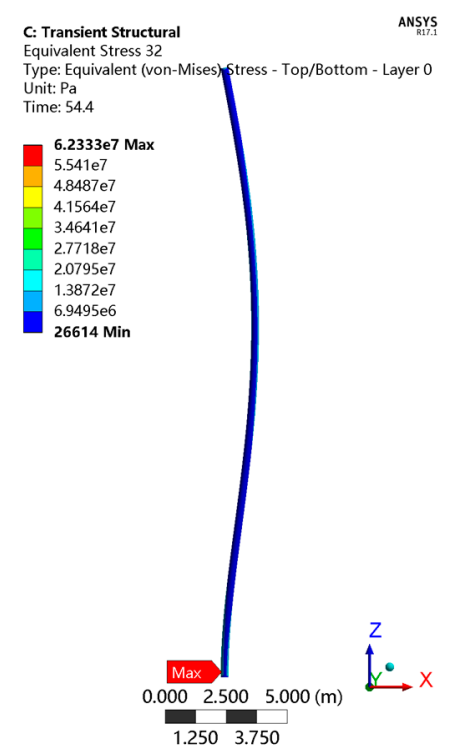

(i) riser 3 at $54.4 \mathrm{~s}$ with $2.13 \mathrm{~m} / \mathrm{s}$

Figure 12. Maximum von Mises stresses of the risers (a) riser 1 at $72.6 \mathrm{~s}$ with $0.36 \mathrm{~m} / \mathrm{s}$, (b) riser 2 at $30.6 \mathrm{~s}$ with $0.36 \mathrm{~m} / \mathrm{s}$, (c) riser 3 at $24.6 \mathrm{~s}$ with $0.36 \mathrm{~m} / \mathrm{s}$, (d) riser 1 at $71.0 \mathrm{~s}$ with $1.22 \mathrm{~m} / \mathrm{s}$, (e) riser 2 at $52.6 \mathrm{~s}$ with $1.22 \mathrm{~m} / \mathrm{s}$, (f) riser 3 at $68.0 \mathrm{~s}$ with $1.22 \mathrm{~m} / \mathrm{s}$, (g) riser 1 at $46.6 \mathrm{~s}$ with $2.13 \mathrm{~m} / \mathrm{s}$, (h) riser 2 at $39.8 \mathrm{~s}$ with $2.13 \mathrm{~m} / \mathrm{s}$, (i) riser 3 at $54.4 \mathrm{~s}$ with $2.13 \mathrm{~m} / \mathrm{s}$.

\subsection{Stress Distributions in Every Layer of the FRP Composite Risers}

For each case, there were two significant times, when the maximum displacement occurred and the maximum stresses occurred. Comparing the stresses in the FRP composite layers at these two time points, the maximum stresses in every lamina of FRP composite risers (risers 2 and 3) were obtained and the factor of safety (FS) are presented in Figures 13-15. Here, the factor of safety was defined as allowable strength/stress.

In composite riser design, the factor of safety was utilised to verify the stress failure. In this paper, the maximum stress failure criterion [47] considered failures in the fiber direction, transverse 
direction and in-plane shear separately for all composite layers. The minimum FS required was 1.53 for composite layers and 1.68 for titanium liner [46].

For cases with velocity of $0.36 \mathrm{~m} / \mathrm{s}$ for riser 2, the maximum von Mises stress in the titanium liner is $3 \mathrm{MPa}$ and FS $=293$. Figure 13a,b, respectively, show the minimum FSs in the fiber and transverse directions for all the layers of riser 2 . Here, it was noted that for the riser geometry with only orthotropic reinforcements (riser 2), the shear stresses in all layers were small enough to be neglected. The minimum FS in the fiber direction was 493 (layer 20 in Figure 13a) while that in the transverse direction is 168 (layers 21 in Figure 13b). It is evident that, for riser 2 with $0.36 \mathrm{~m} / \mathrm{s}$, the in-plane transverse stresses were the most critical stresses and they were far away from the failure stresses.

For cases with velocity of $0.36 \mathrm{~m} / \mathrm{s}$ for riser 3, the maximum von Mises stress in the titanium liner was 5.2 MPa and FS = 169. Figure 13c-e, respectively, show the minimum FSs in the fiber, transverse and shear directions for all the layers of riser 3. The minimum FS in the fiber direction were 304 (layer 3 in Figure 13c), 73.7 (layer 17 in Figure 13d in the transverse direction and 273 in shear direction (layer 13 in Figure 13e). It was evident that, for riser 3 with $0.36 \mathrm{~m} / \mathrm{s}$, the in-plane transverse stresses were the most critical stresses and much smaller than those in riser 2 . They were, however, far away from the failure stresses.

Comparing the FS (s) in riser 2 and riser 3, it was obvious that the tailor-designed composite riser 3 could take advantage of the fiber strength more efficiently.

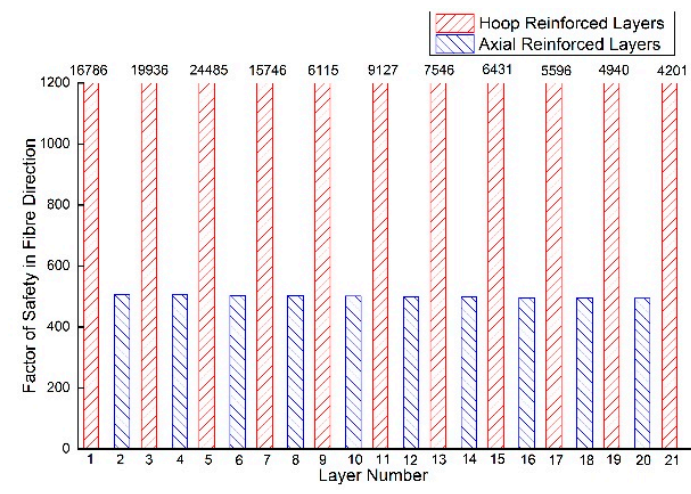

(a) riser 2-fiber direction

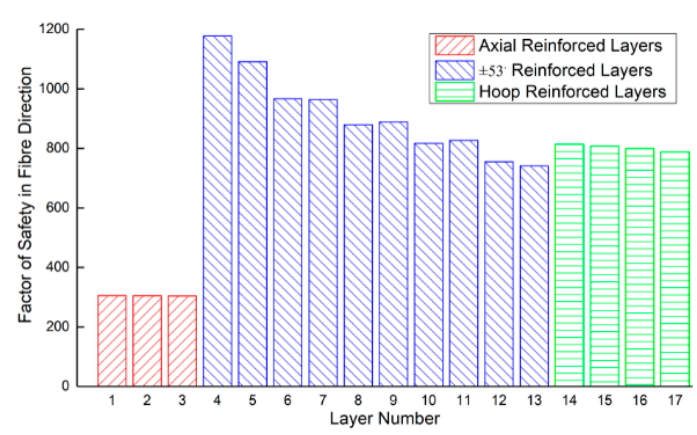

(c) riser 3-fiber direction

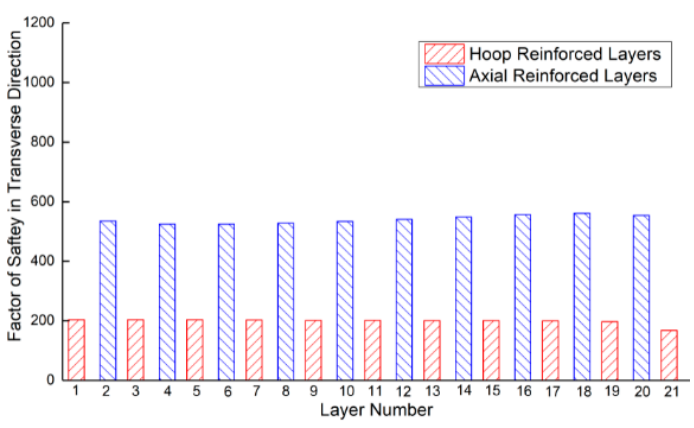

(b) riser 2-transverse direction

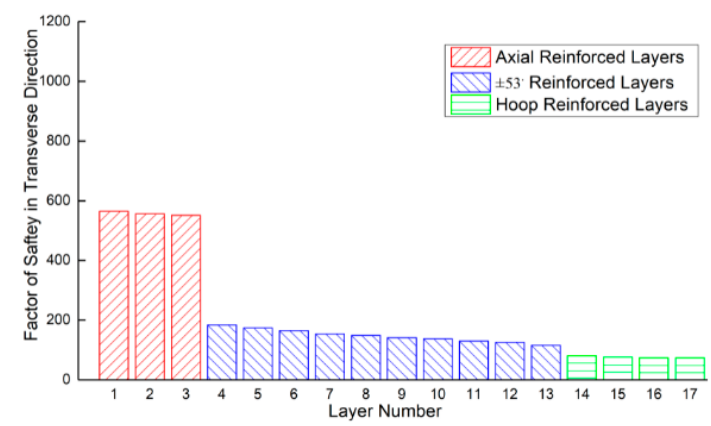

(d) riser 3-transverse direction

Figure 13. Cont. 


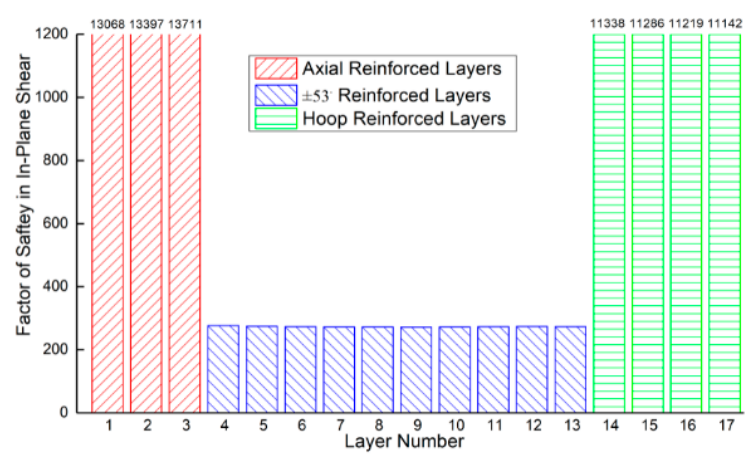

(e) riser 3-shear direction

Figure 13. Factor of safety of composite layers for $0.36 \mathrm{~m} / \mathrm{s}$ in (a) riser 2-fiber direction, (b) riser 2-transverse direction, (c) riser 3-fiber direction, (d) riser 3-transverse direction and (e) riser 3-shear direction.

For cases with velocity of $1.22 \mathrm{~m} / \mathrm{s}$ for riser 2, the maximum von Mises stress in the titanium liner was 11.2 MPa and FS = 78. Figure 14a,b, respectively, show the minimum FSs in the fiber and transverse directions for all the layers of riser 2 . Here, it was noted that for the riser geometry with only orthotropic reinforcements (riser 2), the shear stresses in all layers were small enough to be neglected. The minimum FS in the fiber direction was 120 (layer 20 in Figure 14a) while that in the transverse direction was 43.7 (layers 21 in Figure 14b). It was evident that, for riser 2 with $1.22 \mathrm{~m} / \mathrm{s}$, the in-plane transverse stresses were the most critical stresses and they were far away from the failure stresses.

For cases with velocity of $1.22 \mathrm{~m} / \mathrm{s}$ for riser 3 , the maximum von Mises stress in the titanium liner was $22.4 \mathrm{MPa}$ and FS = 39. Figure 14c-e, respectively, show the minimum FSs in the fiber, transverse and shear directions for all the layers of riser 3. The minimum FS in the fiber direction were 71.4 (layer 3 in Figure 14c), 24.2 (layers 17 in Figure 14d) in the transverse direction and 60.3 in the shear direction (layer 13 in Figure 14e). It was evident that, for riser 3 with $1.22 \mathrm{~m} / \mathrm{s}$, the in-plane transverse stresses were the most critical stresses and much smaller than those in riser 2 . But they were far away from the failure stresses.

Comparing the FS (s) in riser 2 and riser 3, it was obvious that tailor-designed composite riser 3 could take advantage of the fiber strength more efficiently.

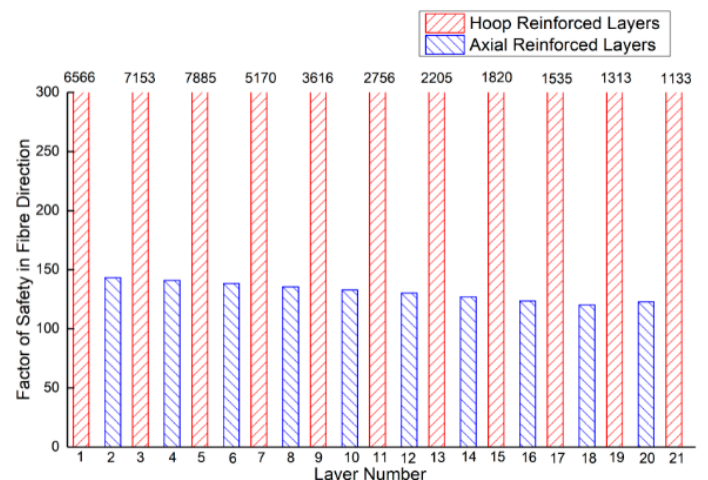

(a) riser 2-fiber direction

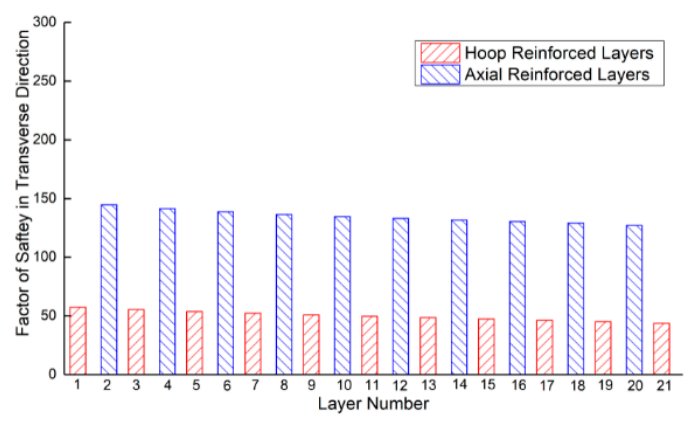

(b) riser 2-transverse direction

Figure 14. Cont. 


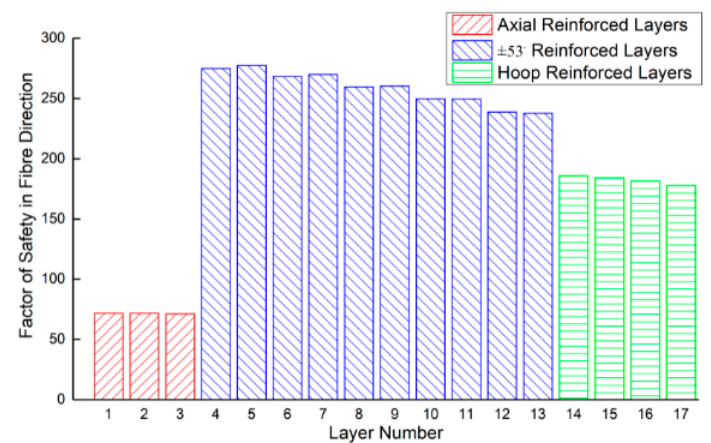

(c) riser 3-fiber direction

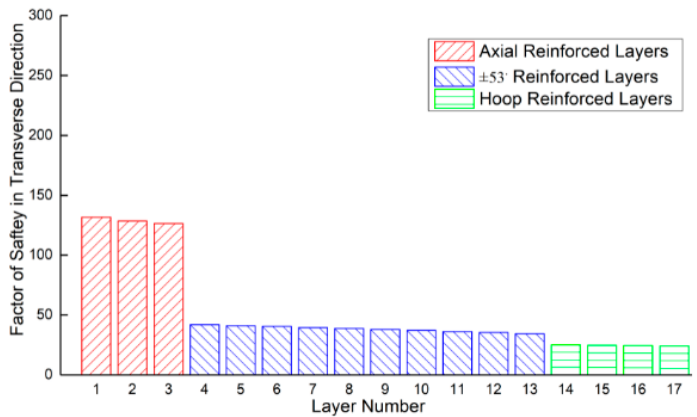

(d) riser 3-transverse direction

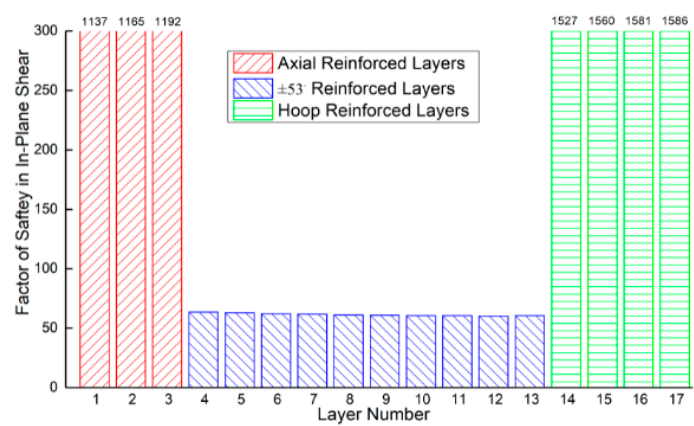

(e) riser 3-shear direction

Figure 14. Factor of safety of composite layers for $1.22 \mathrm{~m} / \mathrm{s}$ in (a) riser 2-fiber direction, (b) riser 2-transverse direction, (c) riser 3-fiber direction, (d) riser 3-transverse direction and (e) riser 3-shear direction.

For cases with velocity of $2.13 \mathrm{~m} / \mathrm{s}$ for riser 2, the maximum von Mises stress in the titanium liner was 29.3 MPa and FS = 30. Figure 15a,b, respectively, show the minimum FSs in the fiber and transverse directions for all the layers of riser 2 . Here, it was noted that for the riser geometry with only orthotropic reinforcements (riser 2), the shear stresses in all layers were small enough to be neglected. The minimum FS in the fiber direction was 35.3 (layer 20 in Figure 15a) while that in the transverse direction was 16.1 (layers 21 in Figure 15b). It was evident that, for riser 2 with $2.13 \mathrm{~m} / \mathrm{s}$, the in-plane transverse stresses were the most critical stresses and they were far away from the failure stresses.

For cases with velocity of $2.13 \mathrm{~m} / \mathrm{s}$ for riser 3, the maximum von Mises stress in the titanium liner was $58.1 \mathrm{MPa}$ and FS $=15$. Figure $15 \mathrm{c}-\mathrm{e}$, respectively, show the minimum FSs in the fiber, transverse and shear directions for all the layers of riser 3. The minimum FS in the fiber direction were 22.5 (layer 3 in Figure 15c), 12.9 (layers 17 in Figure 15d in the transverse direction and 22.8 in shear direction (layer 13 in Figure 15e). It was evident that, for riser 3 with $2.13 \mathrm{~m} / \mathrm{s}$, the in-plane transverse stresses were the most critical stresses and much smaller than those in riser 2. But they were far away from the failure stresses.

Comparing the FS (s) in riser 2 and riser 3, it was obvious that tailor-designed composite riser 3 could take advantage of the fiber strength more efficiently. 


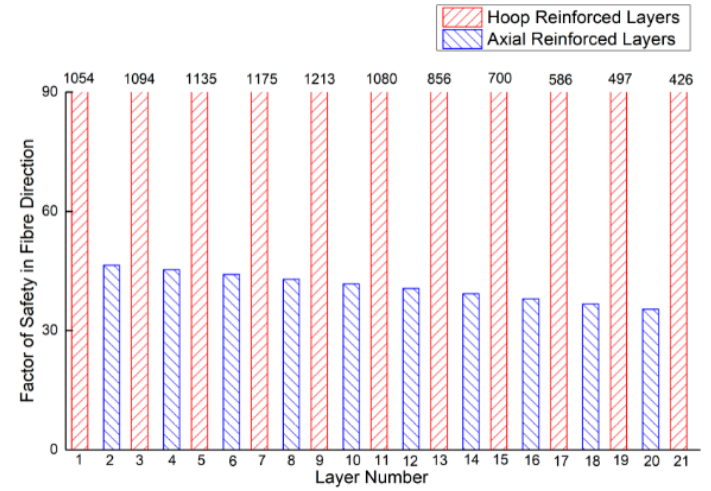

(a) riser 2-fiber direction

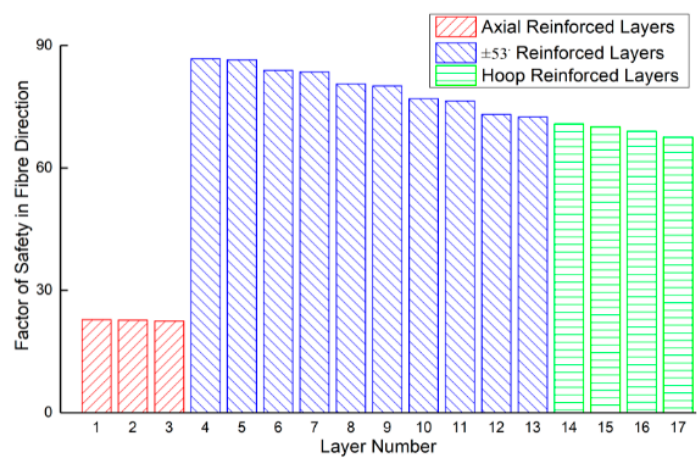

(c) riser 3-fiber direction

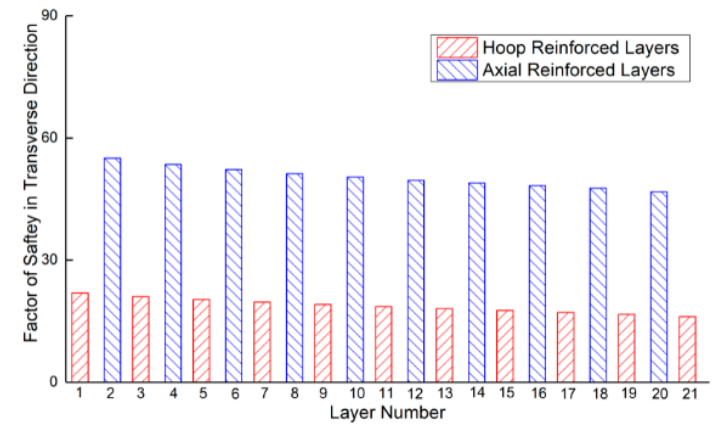

(b) riser 2-transverse direction

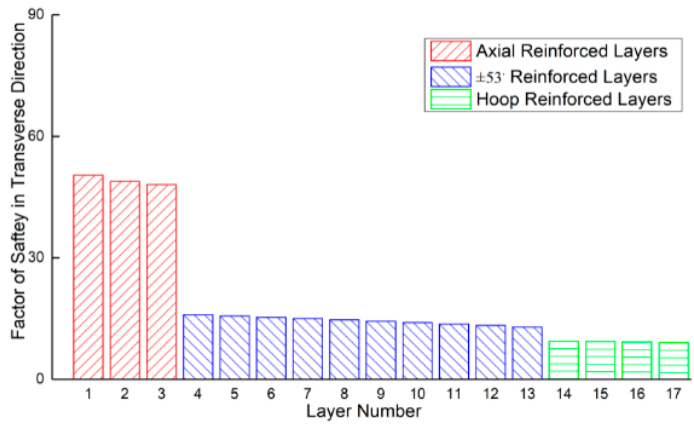

(d) riser 3-transverse direction

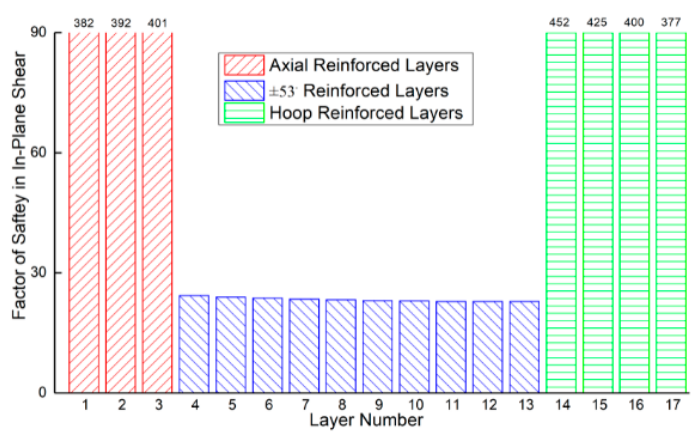

(e) riser 3-shear direction

Figure 15. Factor of safety of composite layers for $2.13 \mathrm{~m} / \mathrm{s}$ in (a) riser 2-fiber direction, (b) riser 2-transverse direction, (c) riser 3-fiber direction, (d) riser 3-transverse direction and (e) riser 3-shear direction.

\section{Conclusions}

This paper presents a comparative VIV study of FRP composite risers (AS4-epoxy with titanium liner) with two geometries ([liner $\left./ 90 /(0 / 90)_{10}\right]$ and $\left[\right.$ liner $\left.\left./ 0_{3} /(+53,-53)_{5} / 90_{4}\right]\right)$ using a steel riser as the benchmark. The CFD simulation with coupled fluid-structure interaction was employed for nine different study cases considering a combination of different risers, tension forces, buoyancies, gravities and current conditions to investigate each riser's VIV characteristics including their natural 
frequencies, global displacements, global stresses and the stress distributions in every layer of the FRP composite risers. The results showed that:

(1) VIV responses of displacements for all three risers at $2.13 \mathrm{~m} / \mathrm{s}$ were about 30 times of those at $0.36 \mathrm{~m} / \mathrm{s}$ and 3 times of those at $1.22 \mathrm{~m} / \mathrm{s}$; VIV responses of global stresses for all three risers at $2.13 \mathrm{~m} / \mathrm{s}$ were about 10 times of those at $0.36 \mathrm{~m} / \mathrm{s}$ and 3 times of those at $1.22 \mathrm{~m} / \mathrm{s}$; and only in the 100 year loop current condition $(2.13 \mathrm{~m} / \mathrm{s})$, “lock-in" might occur for steel riser (riser 1 ) and optimized FRP composite riser (riser 3).

(2) Displacements in in-line flow direction maintained at a relatively stable value and vibrated slightly after the initial growth, while the vibration in cross flow direction was obvious. In terms of the total displacement, that of the optimized FRP composite riser was the largest and that of steel riser was the smallest, i.e., the maximum total displacement for riser 3 was about three times of that for riser 1 and two times of that for riser 2 at all flow velocities.

(3) End support conditions affected the displacement significantly, i.e., simple support lead to larger displacement compared to the fixed support.

(4) Maximum von Mises stresses occurred at the top/bottom end of all risers, followed by the middle parts (above the middle point) of the risers, while at about $-19 \mathrm{~m}$, the minimum von Mises stresses happened. When the maximum von Mises stresses occurred at the top end, the top tension force played a key role, and when the maximum von Mises stresses occurred at the bottom end, the bending force was the most significant one. For the middle part, both tension and bending forces were essential.

(5) The conventional FRP composite riser (riser 2) had the largest FS (168, 43.7 and 16.1 for $0.36 \mathrm{~m} / \mathrm{s}, 1.22 \mathrm{~m} / \mathrm{s}$ and $2.13 \mathrm{~m} / \mathrm{s}$, respectively) while the optimized FRP composite riser (73.7, 24.2 and 12.9 for $0.36 \mathrm{~m} / \mathrm{s}, 1.22 \mathrm{~m} / \mathrm{s}$ and $2.13 \mathrm{~m} / \mathrm{s}$, respectively) and steel riser $(82.4,31.6$ and 12.1 for $0.36 \mathrm{~m} / \mathrm{s}$, $1.22 \mathrm{~m} / \mathrm{s}$ and $2.13 \mathrm{~m} / \mathrm{s}$, respectively) had the similar FS, indicating the optimized composite riser could take advantage of the fiber strength more efficiently.

Author Contributions: Conceptualization, C.W.; methodology, C.W. and S.G.; validation, C.W. and S.G.; formal analysis, S.G.; investigation, M.S.; data curation, S.G.; writing-original draft preparation, C.W. and S.G.; writing-review and editing, C.W.; supervision, C.W. and B.H.; project administration, C.W. and Z.J.; funding acquisition, C.W.

Funding: This research was funded by the Shandong Provincial Natural Science Foundation (ZR2017LEE031), National Natural Science Foundation of China (51806130) and the Science and Technology Development Project of Zibo (2017KJ040017).

Conflicts of Interest: The authors declare no conflict of interest.

\section{References}

1. American Petroleum Institute (API). Design of Risers for Floating Production Systems (FPSs) and Tension-Leg Platforms (TLPS); American Petroleum Institute: Washington, DC, USA, 1998.

2. Chakrabarti, S.K. Handbook of Offshore Engineering, 1st ed.; Elsevier: London, UK, 2005; Volume 1.

3. Balazs, G.L.; Borosnyoi, A. Long-term behavior of FRP. In Composites in Construction: A Reality; Edoardo, C., Gaetano, M., Antonio, N., Eds.; American Society of Civil Engineers: Reston, VA, USA, 2001; pp. 84-91.

4. Jansons, J.O.; Glejbol, K.; Rytter, J.; Aniskevich, A.N.; Arnautov, A.K.; Kulakov, V.L. Effect of water absoption, elevated temperatures and fatigue on the mechanical properties of carbon-fiber-reinforced epoxy composites for flexible risers. Mech. Compos. Mater. 2002, 38, 299-310. [CrossRef]

5. Salama, M.M.; Martinussen, E.; Spencer, B.; Hanna, S.; Hsu, T.M.; Stjern, G.; Franco, E.; Storhaug, T.; Echtermeyer, A. Composite risers are ready for field applications-status of technology, field demonstration and life cycle economics. In Proceedings of the 13th Annual Deep Offshore Technology Conference, Rio de Janerio, Brazil, 17-19 October 2001.

6. Venkatesan, R.; Dwarakadasa, E.S.; Ravindran, M. Study on behavior of carbon fiber-reinforced composite for deep sea applications. In Proceedings of the Offshore Technology Conference, Houston, TX, USA, 6-9 May 2002. 
7. Ochoa, O.O.; Salama, M.M. Offshore composites: Transition barriers to an enabling technology. Compos. Sci. Technol. 2005, 65, 2588-2596. [CrossRef]

8. Ochoa, O.O.; Ross, G.R. Hybrid composites: Models and tests for environmental aging. J. Reinf. Plast. Compos. 1998, 17, 787-799. [CrossRef]

9. Ross, G.R.; Ochoa, O.O. Environmental effects on unsymmetric composite laminates. J. Thermoplast. Compos. Mater. 1991, 4, 266-284. [CrossRef]

10. Bismarck, A.; Hofmeier, M.; Dörner, G. Effect of hot water immersion on the performance of carbon reinforced unidirectional poly(ether ether ketone) (peek) composites: Stress rupture under end-loaded bending. Compos. Part A 2007, 38, 407-426. [CrossRef]

11. Bedon, C.; Louter, C. Numerical investigation on structural glass beams with GFRP-embedded rods, including effects of pre-stress. Compos. Struct. 2018, 184, 650-661. [CrossRef]

12. Karayaka, M.; Wu, S.; Wang, S.; Lu, X.; Partha Ganguly, B.P. Composite production riser dynamics and its effects on tensioners, stress joints, and size of deep water tension leg platform. In Proceedings of the Offshore Technology Conference, Houston, TX, USA, 4-7 May 1998.

13. Huang, K.Z. Composite TTR design for an ultradeepwater TLP. In Proceedings of the Offshore Technology Conference, Houston, TX, USA, 2-5 May 2005.

14. Kim, W.K. Composite Production Riser Assessment. Ph.D. Thesis, Texas A\&M University, College Station, TX, USA, 2007.

15. Beyle, A.I.; Gustafson, C.G.; Kulakov, V.L.; Tarnopol'skii, Y.M. Composite risers for deep-water offshore technology: Problems and prospects. 1. Metal-composite riser. Mech. Compos. Mater. 1997, 33, 403-414. [CrossRef]

16. Ward, E.G.; Ochoa, O.O.; Kim, W.; Gilbert, R.M.; Jain, A.; Miller, C.; Denison, E. A Comparative Risk Analysis of Composite and Steel Production Risers; Texas A\&M University: College Station, TX, USA, 2007.

17. Rakshit, T.; Atluri, S.; Dalton, C. VIV of a composite riser at moderate Reynolds number using CFD. J. Offshore Mech. Arct. Eng. 2008, 130, 011009. [CrossRef]

18. Omar, A.F.; Karayka, M.; Murray, J.J. A comparative study of the performance of top-tensioned composite and steel risers under vertex-induced loading. In Proceedings of the Offshore Technology Conference, Houston, TX, USA, 3-6 May 1999.

19. Wang, C.; Sun, M.; Shankar, K.; Xing, S.; Zhang, L. CFD simulation of vortex induced vibration for FRP composite riser with different modeling methods. Appl. Sci. 2018, 8, 684. [CrossRef]

20. Wang, C.; Shankar, K.; Morozov, E.V. Global design and analysis of deep sea FRP composite risers under combined environmental loads. Adv. Compos. Mater. 2017, 26, 79-98. [CrossRef]

21. Wang, C.; Shankar, K.; Ashraf, M.A.; Morozov, E.V.; Ray, T. Surrogate-assisted optimisation design of composite riser. Proc. Inst. Mech. Eng. Part L 2016, 230, 18-34. [CrossRef]

22. Wang, C.; Shankar, K.; Morozov, E.V. Tailored design of top-tensioned composite risers for deep-water applications using three different approaches. Adv. Mech. Eng. 2017, 9, 1-18. [CrossRef]

23. Chen, Y.; Seemann, R.; Krause, D.; Tay, T.-E.; Tan, V.B. Prototyping and testing of composite riser joints for deepwater application. J. Reinf. Plast. Compos. 2016, 35, 95-110. [CrossRef]

24. Tan, L.B.; Chen, Y.; Jaiman, R.K.; Sun, X.; Tan, V.B.C.; Tay, T.E. Coupled fluid-structure simulations for evaluating a performance of full-scale deepwater composite riser. Ocean Eng. 2015, 94, 19-35. [CrossRef]

25. Toh, W.; Tan, L.B.; Jaiman, R.K.; Tay, T.-E. A comprehensive study on composite risers: Material solution, local end fitting design and global response. Mar. Struct. 2018, 61, 155-169. [CrossRef]

26. Amaechi, C.V.; Nathaniel, G.; Agbomerie, C.O.; Hou, X.; Ye, J. Composite risers for deep waters using a numerical modelling approach. Compos. Struct. 2018, 210, 486-499. [CrossRef]

27. Wang, C.; Shankar, K.; Morozov, E.V. Tailored local design of deep sea FRP composite risers. Adv. Compos. Mater. 2015, 24, 375-397. [CrossRef]

28. Harte, A.M.; McNamara, J.F.; Roddy, I.D. Application of optimisation methods to the design of high performance composite pipelines. J. Mater. Process. Technol. 2003, 142, 58-64. [CrossRef]

29. Harte, A.M.; McNamara, J.F.; Roddy, I. Evaluation of optimisation techniques in the design of composite pipelines. J. Mater. Process. Technol. 2001, 118, 478-484. [CrossRef]

30. Yazdani Sarvestani, H.; Hoa, S.V.; Hojjati, M. Effects of shear loading on stress distributions at sections in thick composite tubes. Compos. Struct. 2016, 140, 433-445. [CrossRef] 
31. Yazdani Sarvestani, H.; Hoa, S.V.; Hojjati, M. Three-dimensional stress analysis of orthotropic curved tubes-part 1: Single-layer solution. Eur. J. Mech. 2016, 60, 327-338. [CrossRef]

32. Ghiasi, H.; Pasini, D.; Lessard, L. Optimum stacking sequence design of composite materials part I: Constant stiffness design. Compos. Struct. 2009, 90,1-11. [CrossRef]

33. Ghiasi, H.; Fayazbakhsh, K.; Pasini, D.; Lessard, L. Optimum stacking sequence design of composite materials part II: Variable stiffness design. Compos. Struct. 2010, 93, 1-13. [CrossRef]

34. Da Silva, R.F.; Teófilo, F.A.; Parente, E., Jr.; de Melo, A.M.; de Holanda, Á.S. Optimization of composite catenary risers. Mar. Struct. 2013, 33, 1-20. [CrossRef]

35. Ahlstone, A.G. Light Weight Marine Riser Pipe. U.S. Patent 3,768,842, 30 October 1973.

36. Sparks, C.P.; Odru, P.; Bono, H.; Metivaud, G. Mechanical testing of high-performance composite tubes for tlp production risers. In Proceedings of the Offshore Technology Conference, Houston, TX, USA, 2-5 May 1988.

37. Salama, M.M.; Johnson, D.B.; Long, J.R. Composite production riser-testing and qualification. SPE Prod. Facil. 1998, 13, 170-177. [CrossRef]

38. Salama, M.M.; Stjern, G.; Storhaug, T.; Spencer, B.; Echtermeyer, A. The first offshore field installation for a composite riser joint. In Proceedings of the Offshore Technology Conference, Houston, TX, USA, 6-9 May 2002.

39. Smith, K.L.; Leveque, M.E. Ultra-Deepwater Production Systems Technical-Progress Report; ConocoPhillips Company: Houston, TX, USA, 2003.

40. Smith, K.L.; Leveque, M.E. Ultra-Deepwater Production Systems-Final Report; ConocoPhillips Company: Houston, TX, USA, 2005.

41. Picard, D.; Hudson, W.; Bouquier, L.; Dupupet, G.; Zivanovic, I. Composite carbon thermoplastic tubes for deepwater application. In Proceedings of the Offshore Technology Conference, Houston, TX, USA, 30 April-3 May 2007.

42. Alexander, C.; Vyvial, B.; Cederberg, C.; Baldwin, D. Evaluating the performance of a composite-reinforced steel drilling riser via full-scale testing for HPHT service. In Proceedings of the 6th International Offshore Pipeline Forum, Houston, TX, USA, 19-20 October 2011.

43. Mintzas, A.; Hatton, S.; Simandjuntak, S.; Little, A.; Zhang, Z. An integrated approach to the design of high performance carbon fibre reinforced risers-From micro to macro-Scale. In Proceedings of the Deep Offshore Technology International Conference, Houston, TX, USA, 6-9 May 2013.

44. Roberts, D.; Hatton, S.A. Development and qualification of end fittings for composite riser pipe. In Proceedings of the Offshore Technology Conference, Houston, TX, USA, 6-9 May 2013.

45. American Bureau of Shipping (ABS). Guide for building and classing subsea riser systems. In Design Requirements and Loads; American Bureau of Shipping: Houston, TX, USA, 2008.

46. Det Norske Veritas (DNV). Offshore Standard for Composite Components (DNV-OS-C501); Det Norske Veritas: Oslo, Norway, 2009.

47. Kaw, A.K. Mechanics of Composite Materials, 2nd ed.; CSC Press: Wilmington, DE, USA, 2006.

48. Bedon, C.; Louter, C. Structural glass beams with embedded GFRP, CFRP or steel reinforcement rods: Comparative experimental, analytical and numerical investigations. J. Build. Eng. 2019, 22, 227-241. [CrossRef]

49. American Petroleum Institute (API). Recommended Practice for Planning, Designing and Constructing Fixed Offshore Platforms-Working Stress Design; American Petroleum Institute: Washington, DC, USA, 2000.

50. Blevins, R.D. Flow-Induced Vibratin, 2nd ed.; Krieger Publishing Company: Malabar, FL, USA, 2001.

(C) 2019 by the authors. Licensee MDPI, Basel, Switzerland. This article is an open access article distributed under the terms and conditions of the Creative Commons Attribution (CC BY) license (http://creativecommons.org/licenses/by/4.0/). 